\title{
Armenian Secret and Invented Languages and Argots
}

\section{Citation}

Russell, James R. Forthcoming. Armenian secret and invented languages and argots.

Proceedings of the Institute of Linguistics of the Russian Academy of Sciences.

\section{Permanent link}

http://nrs.harvard.edu/urn-3:HUL.InstRepos:9938150

\section{Terms of Use}

This article was downloaded from Harvard University's DASH repository, and is made available under the terms and conditions applicable to Open Access Policy Articles, as set forth at http:// nrs.harvard.edu/urn-3:HUL.InstRepos:dash.current.terms-of-use\#OAP

\section{Share Your Story}

The Harvard community has made this article openly available.

Please share how this access benefits you. Submit a story.

\section{Accessibility}




\section{ARMENIAN SECRET AND INVENTED LANGUAGES AND ARgOTS.}

By James R. Russell, Harvard University.

Светлой памяти Карена Никитича Юзбашяна посвящается это исследование.

\section{CONTENTS:}

Preface

1. Secret languages and argots

2. Philosophical and hypothetical languages

3. The St. Petersburg Manuscript

4. The Argot of the Felt-Beaters

5. Appendices:

1. Description of St. Petersburg MS A 29

2. Glossary of the Ruštuni language

3. Glossary of the argot of the Felt-Beaters of Moks

4. Texts in the "Third Script" of MS A 29

List of Plates

Bibliography

PREFACE

Much of the research for this article was undertaken in Armenia and Russia in June and July 2011 and was funded by a generous O'Neill grant through the Davis Center for Russian and Eurasian Studies at Harvard. For their eager assistance and boundless hospitality I am grateful to numerous friends and colleagues who made my visit pleasant and successful. For their generous assistance in Erevan and St. Petersburg I would like to express particular thanks to Dr. Erna Shirinian, Matenadaran Institute of Ancient Manuscripts, Erevan; Professor Muhammad Dandamayev, St. Petersburg State University and the Institute of Oriental Studies of the Russian Academy of Sciences; and Dr. Valerii Nikanorov, Institute of Ethnography, Russian Academy of Sciences, St. Petersburg. For their help in searching for material on the invented Seh-lerai language I am grateful to many friends and colleagues, including Michael Grossman of the Middle East Division of the Widener Library, Harvard University, Cambridge, MA: Dr. Raffi Tingir, New York; to Dr. Arika Okrent, Philadelphia, PA; Dr. Olga Kerziouk of the Esperanto division of the British Library, London; Prof. Johann Strauss of the University of Strasbourg; to Dr. Raymond Kevorkian, Director of the AGBU Nubarian Library, Paris; Prof. Valentina Calzolari of the University of Geneva; the staff of the Planned Languages collection of the Austrian National Library, Vienna; and Osman Köker, Birzamanlar Yayıncılık, Istanbul. And as so often, I have profited from the conversation and learning of my friend Marc Mamigonian, Academic Director of the National Association for Armenian Studies and Research, Belmont, MA. 
In September 1982, in the days of the Armenian voske ašun, the "golden autumn", the Institute of Linguistics of the Academy of Sciences of the Armenian Soviet Socialist Republic hosted an international conference on Armenian linguistics. That Armenia was able to do this in one of the frostier years of the Cold War was itself an aspect of the unique, even charmed, status of what the Russian poet Osip Mandelstam had called the "Sunday country", the sunny sliver of the civilized Mediterranean world, the place of rest within the laboring Soviet Union. One session of the conference was held at the Matenadaran, that Parthian temple of ancient manuscripts that looks out from the brow of its hill down Erevan's central avenue (then Lenin, now named Maštoc', after the inventor of the Armenian alphabet) and out towards the snowy, inaccessible peak of Ararat. Prof. Karen Yuzbashian and I became acquainted then. Just as I purchased a stack of books, the news came through on the wireless that the export of books had been forbidden, by decree of the Supreme Soviet. Ia etogo prosto ne poimu, "I don't understand it," I murmured in exasperation to Karen Nikitich, who by way of reply made a sweeping gesture as if to embrace the entire USSR and asked, A ostal'noe, Vy ponimaete? "And the rest you do understand?" We passed quickly from vous to $t u$; and his ironic remark was the first bon mot of many I was to hear over the long years of our friendship, which ended, only on the earthly plane, with his passing in March 2009. His paper that day had dealt with an invented language, the $\dot{R} u s ̌ t u n i ~ l e z u$, a word-list of which he had discovered in a Leningrad manuscript he was cataloguing. The list had been published by its previous owner nearly a century before. Karen modestly concluded that he had nothing of importance to add to some preliminary and tentative suggestions, and, though I returned to the subject in conversation over the years, he did not publish his paper. And there things stood. In 2011 I studied a cipher manuscript at Erevan, and from there, after an absence of four years, I returned to St. Petersburg, Mandelstam's gorod, znakomyi do slëz, the city familiar to the point of tears, intending to study a manuscript containing three unusual Armenian cipher alphabets. As I perused it I discovered with a sharp, tender shock that it was the very one where Karen had found his enigmatic $\dot{R} u s ̌ t u n i$ language. I copied out the glossary and decided it deserved another go.

Whether I am right, the reader can decide. But I thought that the list deserved publication in English, in the context of a general consideration of Armenian and other planned languages and argots; and I was intrigued that Ruštuni came with its own elegant cipher script (the third of the three in the MS; so after the Persian khatt-e sevvom I have named it the "Third Script"), one which its inventor employed mainly, though not, it would seem, exclusively, for the encoding of magical spells that are of considerable anthropological and botanical interest in their own right. A few days after I had begun perusing MS A 29, my friends Oksana Nikol'skaia and Khachatur Bely visited Karen's grave in the Armenian cemetery on Vasil'evskii Island and placed flowers there. Then we went to Khachatur's studio near Vosstanie Square and ate Armenian lavash bread and cheese, three gathered in His name.

Karen's manuscript, A 29 at the Institute of Oriental Studies of the Russian Academy of Sciences on the Palace Embankment, lives in a library situated on the second floor of an $18^{\text {th }}$-century palace; and in the reading room, the Zelënyi zal or Green Hall, if you listen very carefully you can sense Alexander Pushkin's blesk, i shum, i govor 
balov - the sparkling light, and sound, and speech of balls. The windows, many times the height of a man, take in the refracted glitter of the waters of the broad Neva; and at noon the cannon fired at the Peter and Paul Fortress opposite shakes their panes. Shortly after I had parted with the ghosts of cavalry officers and princesses, The New York Times published a glib article by James Gleick asserting that for all the pleasure he once felt when handling an ancient manuscript, the digital experience has fairly replaced it. Let him keep on thinking it: I had the Green Hall to myself.

This study, then, addresses the topic of Armenian secret languages and argots in a historical, cross-cultural, linguistic, and social context, considering the invented language and cipher script of MS A 29, another curious case of Armenian invented language (Sehlerai), and the secret argot of the felt-beaters of Moks.

\section{SECRET LANGUAGES AND ARGOTS}

"When a people preserves its language, it preserves the marks of liberty," intoned the $19^{\text {th }}$-century Filipino nationalist José Rizal. One might add that since the condition of unfreedom is more the norm than liberty, secret languages and ciphers have long been devised. Perhaps secret language is as old as human society itself. Its purposes and uses are quite varied; but there seem to be a few that are most frequent. Jargon has been defined as the specialized vocabulary of conventional groups in society - the brevity of accepted terms is convenient, it has to be learned, but there is nothing intrinsically secret about it. Argot, on the other hand, can be defined as a system of non-verbal symbols, vocabulary, and verbal expressions within a natural language that is used expressly for the purpose of concealment. The reason for secrecy in this case is criminal or deviant behavior (as fluctuatingly defined by the dominant culture of the time); and the argot serves the additional function of affirming membership in the in-group and of validating its antinomian character. It is a "boundary-maintaining mechanism" in which words for outsiders are pejorative; for insiders, euphemistic and even laudatory. In the prison argot of West Bengal, for instance, a notorious character is called Rustam. ${ }^{1}$ The latter is the mighty Saka warrior whose heroic exploits pervade the $\breve{S} \bar{a} h$-name "Book of Kings" of Ferdōsī - the national epic of Iran popular throughout the East. To call a man Rustam is not merely to praise him, but to evoke, at least to an extent, the heroic code of an archaic culture. Argots can, thus, have a markedly ancient component, as we shall see also in the case of the felt-makers' coded speech in Moks. This is worth keeping in mind, since at least in American English the idea of slang often carries with it, to the contrary, the aspect of novelty and of rapid change. ${ }^{2}$ But it can just as often be a magical window affording a glimpse into antiquity.

Some subgroups are either integrated into society or destroyed; and their argots either lapse into desuetude, are absorbed into mainstream speech, or endure in part in the

\footnotetext{
${ }^{1}$ Lerman 1967, Mehrotra 1977, pp. 8, 9.

${ }^{2}$ This is particularly the case with the African-American "gangsta" parlance of the inner city; and websites such as Urban Dictionary enable one to track the speed and flux of such linguistic change.
} 
argots of other subcultures. The Greek military régime of 1967-1975 repressed the scholar Elias Petropoulos for his work on the argot of Greek homosexuals, Kaliarda, with its enormous vocabulary. ${ }^{3}$ Farrell in 1972, three years after the Stonewall uprising, could still title an article on the speech of American gays "The Argot of the Homosexual Subculture". However the Greek junta collapsed, Gay liberation advanced, Kaliarda has gone into many editions and is a standard work of research, and gay people in most civilized nations need no longer conceal their way of life, nor do repressive laws force them to consort with criminals. So now expressions Farrell classified two generations ago as argot - "get real", "get lost", "tacky", "bummer", etc. - have found their way into the mainstream of American English. Other terms that reified the subcultural and deviant character of gay life have faded away as homosexuality itself has come out of the "closet" and its distinctive subcultural traits have mostly melted away. ${ }^{4}$

The Thugs, a criminal (by any definition) subculture of the Indian subcontinent were another, quite different, deviant group with a patois of their own: masquerading as guides or helpers, they would attach themselves to bands of travelers, exchange signs of recognition and instructions in their argot, and then strangle, rob, and bury their victims, dedicating the murders as offerings to the goddess Kali. Nothing remains of this group but its name; for the British were able in the $19^{\text {th }}$ century to rid India of this ancient scourge. ${ }^{5}$ But some lexical items of the Thugs entered the argot of other deviant groups who are only marginally criminal. The Pandas of Varanasi are a class of priestly practitioners and guides who fleece pilgrims to the holy city on the Ganges. ${ }^{6}$ In addition to using pure neologisms such as khotar for "policeman", they sardonically endow innocuous expressions with deviant meanings: panditjī, lit. "estimable Sanskrit scholar" means "marijuana"; and tirāth karna "make pilgrimage" is used to mean "to get drunk". Pandas of Varanasi and Dalals - silk merchants - of Delhi have absorbed into their lexicon a number of words and code names for numbers from Thug argot. ${ }^{7}$ This use of symbolic nouns and proper names for numbers would be of particular value in concealing financial transactions; and Al Bīrūn̄̄ noted their use in India a millennium ago. ${ }^{8}$

Secret codes have also been employed by creative artists and dissidents in societies terrorized by state surveillance and repression, notably in the Soviet Union. A case in point is the great Armenian poet Ełiše Č 'arenc' (generally rendered in English as

\footnotetext{
${ }^{3}$ Petropoulos 1982.

${ }^{4}$ Farrell 1972.

${ }^{5}$ Sleeman 1836.

6 "Pandas of today earn their living by goondagiri," as the newspaper Aaj (i.e., Hindi āj, "today") of 8 June 1973 (cit. Mehrotra 1977, p. 24) puts it in endearingly quaint Indian English. A gunda is a hoodlum; gundagiri, well, thuggery!

${ }^{7}$ Mehrotra 1977, pp. 32, 35-36, 39, 88.

${ }^{8}$ Mehrotra 1977 offers several examples: for zero, akāśa ("space”), śunya ("voidness"); one, adi ("beginning"), rupa ("form"); two, Yama (lord of the underworld, the primordial Twin), Aśvin (twin horsemen); three, trikāla ("three times", i.e., past, present, future), loka ("(3) worlds", i.e., heaven, hell, and this); etc. Here sacerdotal arcana, the philosophy of mathematics, and perhaps commercial secrecy intersect.
} 
Charents, b. Kars, Russian Armenia, 1897). He was ostracized from society, then arrested and murdered by the police in 1937. Shortly before his death he drafted the first stanzas of the unfinished epic Poema anvernagir "Poema without a title" whose epigraph contains the enigmatic line: $I T^{\prime}+L A+A+\check{Z} B+\check{Z} A+I B+\check{C} Z$, which can be deciphered by considering each number the ordinal place of a character in the Armenian alphabet, so: $\mathrm{S}+\mathrm{T}+\mathrm{A}+\mathrm{L}+\mathrm{I}+\mathrm{N}=106$. $\check{\mathrm{C}}^{\prime}$ arenc $^{\text {' }}$ seems to be seeking the mystico-numerical significance (in Jewish mysticism this is called gematria) of the sum of the letters of the name of the dictator whom the poet, who was no stranger to every kind of philosophical and ideological contradiction, both revered slavishly as a leader and execrated bitterly as a tormentor. At another point he calls Koba (the Georgian diminutive of Joseph, the

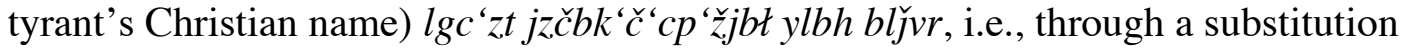
cipher arrived at by transposing the order of the letters, ibrev hełap'oxut'yan miak aspet "as the sole paladin of the Revolution" - the incriminating implication being that the mustachioed bandit from the Caucasus had impudently usurped the nobility of Vladimir Il'ich Lenin. ${ }^{9}$

As early as AD 1250 one encounters in central Europe the German designation Rotwelsch for a Sondersprache intended for use in bypassing social norms of communication and expressing tabooed things. It was a speech of thieves and robbers more than a professional jargon, and contained numerous lexical items from the tongues of marginal or outcast communities - the Jews and the Roma. So for instance the word for a thieves' lair, čor-bayis, contains both the Indic, Romani word for a thief and the Ashkenazic pronunciation of the Hebrew term for a house, bayit. The word krey, "horse", employed in the same argot, is derived from Romani graj, "idem", itself a loan from Arm. grast "beast of burden, pack animal": many of the Roma of Europe had come through Armenia, and their speech in places as remote as Wales contains Armenian lexical items. ${ }^{10}$ The Roma of Armenia in turn employed their speech, Lomavren (i.e., a form of "Roma" + the archaically pronounced Classical Armenian suffix for custom or language -awrēn (now pronounced -ōrēn), Mod. Arm. a/ērēn, cf. hayērēen, "Armenian"), which contained numerous loans from Iranian languages, as a secret jargon. ${ }^{11}$ In the $10^{\text {th }}$ century the Hudüd al- 'älam ("Limits of the world", an Islamic text on geography in

${ }^{9}$ See discussion in Abgaryan 1991, pp. 157-160. A more interesting (but not Armenian) case is that of the Russian absurdist writer Daniil Kharms, who kept an enchanting diary of drawings, Kabbalistic notes, and chronicles of erotic desire in a simple substitution cipher whose letters he culled from sources as mutually remote as Samaritan and Japanese - a reflection of the catholicity of his interests: see Russell 2010. The Soviet graphic designer and architectural draftsman Yakov Chernikhov also invented elegantly typographical cryptograms in the 1930's. He also sketched fanciful landscapes with impossibly elaborate, exotic Indian-style buildings; and it would seem the two exercises of escapist imagination often go together. See Chernikhov 2009, pp. 118-119, 203.

${ }^{10}$ Matras 1998; perhaps the element rot, "red", in the designation Rotwelsch, with its Hebraisms and Jewish associations, can be associated with medieval superstitions about the detested and feared rote Juden, "Red Jews" of the Apocalypse, cf. Gow 1995, Benite 2009, and Russell (2012).

${ }^{11}$ Voskanian 2002. 
Persian) mentions a secret language called lutrā, which Melikian explains as a loan from Hindi/Urdu lutra, "exiled, dumped"- perhaps a deprecatory designation of the itinerant Roma, and thus, presumably, of their speech also. But it would seem the origins of this speech lie in a very ancient argot of Iranian Jews whose encoded words were Aramaic. ${ }^{12}$ The natural languages, then, of Roma and Jews, who were stigmatized as marginal or deviant subcultures, whether for their itinerant way of life or independent religious beliefs, were at times considered argots themselves, or at least contributed to the argots of criminals - so one still finds Hebrew words, via Yiddish, in Russian underworld slang. For instance, Hebrew ketubbah "marriage contract" in its Ashkenazic pronunciation becomes the common Russian slang word ksiva, "document". And then there are the argots that survive their speakers. In Holland, whose Jewish community was almost entirely exterminated in World War II by the Germans, the slang name of Amsterdam is still mókem, from Hebrew māqōm, "place". In Hungary, whose Jewish population was similarly decimated, the slang for a friend or pal endures as haver (pronounced hóver), from Hebrew-in-Yiddish again.

For the $17^{\text {th }}$-century Armenian traders of New Julfa, their native dialect and script served as a secret language on its own; and there were also argots and secret languages within Armenian itself. Armenians of the village of Banazur in the Hadrut region of Arc'ax (Mountainous Karabagh) all knew an Armenian form of the secret language called by the Iranian name Zargarī, lit. "goldsmiths' (argot)", in which one simply adds a -z- to each syllable, e.g., Arm. cnund, "birth" > Zargarī cazənəzund, etc. They employed also reversed speech (Arm. t'arserēn), turning hac " "bread", for example, into c'ah. The ethnographer Sruanjteanc 'cites the same example but calls it sparrows' language (see infra).${ }^{13}$ As we shall see presently, the Armenian felt-makers of Moks at times manipulated words in this way, in order further to complicate their own secret argot.

In his famous discussion, following the funeral oration of Pericles, of the corruption of Athenian society under the pressures of the Peloponnesian War, Thucydides describes how the meaning of words changed: the attributes of a simple and honest nature were derided as naïve, while words describing base and violent qualities came to be praises. But it is the twentieth century, perhaps uniquely, that has provided the case of the

${ }^{12}$ In an important article summarized in the Encyclopaedia Iranica, "Loterai and its long history", Prof. Martin Schwartz (University of California, Berkeley) has studied a $14^{\text {th }}$ century Persian MS of the "Book of Grifters" (Ketāb-e Sāsiyān) containing a glossary of Loterā' $\overline{1}$, an argot defined as employing Judeo-Iranian grammar "with a special substitutive vocabulary which is used in the presence of gentiles to prevent them from understanding." He demonstrates that these substituted or code words are Aramaic, in forms datable to the early Achaemenid period, that is, $c a$. the $6^{\text {th }}-5^{\text {th }}$ cent. BC. ${ }^{13}$ Melikian 2002; Adams 2009, p. 37, citing English nosper for "person" and top o' reeb for "pot of beer", calls this "back slang". My grandmother Bertha Russell (1900-1981), who came from the village of Wolka Turebska near Rozwadów to the Lower East Side of Manhattan in 1906, kept her Yiddish, forgot most of her Polish, and learned English perfectly, both the received type of school and the back slang of the street, whole sentences in which she sometimes recited to me with astonishing speed. 
transformation of an entire national language into the argot, not of a subculture, but of a dominant, majority criminal culture. Victor Klemperer, who before World War II had been a professor of French literature at Dresden University, became an eyewitness to, and survivor of, the horrors of Nazi Germany, keeping clandestine notes on the transformation by the Germans of their own tongue, once the speech of a civilization, into a criminal argot. After the War he gathered his notes into a book, Lingua Tertii Imperii, in which he describes, for instance, how the epithet "fanatical", once a term of opprobrium, became an adjective of approbation. At one point he calls LTI a "prison language". It is important to stress that, unlike in the Soviet Union, where writers and others satirized Party jargon and the Russian language became a bulwark of poets against totalitarianism, the majority of Germans seem to have found a sense of togetherness in the shared knowledge of their implication in the crimes of their Third Reich. Their criminal argot, this Nazified German, it may be argued, both grew out of this collective degeneracy and served to reinforce and validate it. ${ }^{14}$

\section{PHILOSOPHICAL AND HYPOTHETICAL LANGUAGES.}

Some secret languages have been devised, not to conceal criminal activities, but to restrict esoteric teachings to an intellectual or spiritual elite. Their inventors feared misunderstanding by readers insufficiently prepared, as well as persecution by the orthodox establishment. The philosopher Leo Strauss, himself a refugee from fascism, wrote of such practices in medieval Europe in his famous essay, Persecution and the Art of Writing. Zoroastrian sectarians in India, followers of the Parsi priest and esoteric philosopher Dastūr Āzar Kaivān, who flourished in the reign of the emperor Akbar, invented an artificial language for the book of their traditions and teachings, the Desātir. ${ }^{15}$ In a Perso-Turkish milieu of around the $15^{\text {th }}$ or $16^{\text {th }}$ century there was created a language for the use of mystics called Bāl-a i-Balan: it displays characteristics of the languages of its inventors, and was probably invented to conceal esoteric teachings from censorious orthodox divines. ${ }^{16}$

There are traces of such erudite mystification in Armenian MSS. Fr. Nersēs Akinean cites ${ }^{17}$ this autograph of Catholicos Grigoris Ałt' amarc' $i$, a poet who delighted also in macaronic verse: $P$ 'ark' $k$ 'ez kioni: $k^{\prime}$ 'ot arek'sagoyn kisagndi ew Demetri ararič'. Awrhnut'iwn ew p'ark', gohut'iwn ew am(enayn) barexawsut'iwn handerj

${ }^{14}$ LTI Notizbuch eines Philologen was published two years after the war; for an English translation see Klemperer 2000, esp. p. 76. For the argument that knowledge of Nazi barbarism actually united the Germans, see Kühne 2010. The Nazis also employed a code language of concealment and euphemism; so "resettlement" in both documents and official conversation on the program of the extermination of the Jews meant "liquidation". Yücel Güçlü, a functionary of the Turkish government tasked with promoting denial of the historicity of the Armenian Genocide, regularly uses the same mendacious terminology in his "researches".

${ }^{15}$ Russell 1993, p. 87.

${ }^{16}$ Bausani 1954 and 1970, p. $83 \mathrm{f}$.

${ }^{17}$ Akinean 1958, p. 1xi. 
erkrpagut'eamb s(urb) errordut'ean... ("Glory to thee... ? and creator of the hemisphere and of Demeter. Blessing and glory, thanks and all intercession with worship of the holy trinity...") And he cites an earlier example of this enigmatic invocation, from the colophon to a hymnal (Šarakan) dated AD 1335, belonging to one Mkrtič‘ Avtalean of Tigranakert (Amida-Diyarbekir) published by the ethnographer Abp. Garegin Sruanjteanc': $P^{\prime}$ ar $\dot{r}^{\prime}{ }^{\prime} k$ 'ez: hon aregsagon kisagndi ew demetri, ararič yamenayn araracoc" yimanaleac" ew i zgaleac"... ("Glory to thee... ? creator of the hemisphere and of Demeter, from all creatures both intelligible and tangible...”) The word kion may be Greek for "pillar"; the hon arexagon, perhaps corrupted Greek for "the hexagon", so the invocation might be an erudite praise of God, the pillar that extends through the six sides of this kisagund, "hemisphere", down to the underworld of the earth mother Demeter, that is, Armenian Sandaramet - though in Greek myth it is Atlas, not Zeus, who is the pillar ouranou te kai khthonos, "of heaven and earth". If the mysterious kion is indeed Greek, then one might cite the conclusion of a magical spell discussed by Ōdabašyan: ${ }^{18}$ oč erknic" siwn ew getinn geran, oč covun xub, oč ap 'ac" mēj maz busani ew oč ays banis xap 'anumn lini "neither heaven's pillar nor the ground plank, nor yet the seal of the sea - a hair will not sprout on the palm of the hands any more than there can be a warding off of this spell." The eleventh-century scholar Grigor Magistros Pahlawuni, famed for his erudite verbal obscurities, mentions both Demeter and kisagund ("hemisphere") in the same passage of a letter dismissing the magic of Nectanebos (the Egyptian priest-magician who fathered Alexander the Great on the credulous concubine Olympias, in the Alexander Romance of Ps.-Callisthenes). ${ }^{19}$ This would be the earliest collocation of the two easily identifiable marked terms in the code phrase, and thus perhaps the latter's source. And one may cite a colophon, less mythologically enigmatic but still polyglottic, as a further example of learned sacerdotal obscurity cited by Fr. Łewond Ališan from an autograph of the historian Zak'aria of $\mathrm{K}^{\text {'anaker: }}{ }^{20} P^{\prime}$ 'ark $k^{\prime} k$ ' $e z$ apeniaz simakra tmert'ō o Dēou t'antri, a(stua)c im $K^{\prime}$ (risto)s "Glory to thee who art without need (MIr. abeniyāz), simakra (?), O God (Geor. ghmert'i, voc.), O God (Gk. theos, gen. sg., and Latin Deo), O God (Tk. tangrı)."

Then there is the language invented as a game or intellectual exercise by one person, sometimes taken up and used by other people to form an in-group, enjoy secrecy, or even create an artificial, amateur subculture not based upon a shared profession or social status or definition. Thus the Oxford Germanic philologist J.R.R. Tolkien as a private hobby invented a number of languages, some influenced by his studies of the Nibelungenlied and other Germanic epics, others strongly colored by Finnish, which he admired for its euphony; and this pastime, which he candidly confessed to as "a secret vice", became the basis of the Lord of the Rings cycle of epic romance and myth. The Ruštuni language seems to belong to this category - it was for its maker an intriguing and private pastime. But private fantasies, as we can see with Tolkien's vast legacy, spread into popular culture and imagination. A martial empire of alien beings, the

${ }^{18}$ Ōdabašyan 2000, p. 47, citing his previous article in Patma-banasirakan handes 1986.3.

${ }^{19}$ Kostaneanc' 1910 , letter 49, pp. 116-117.

${ }^{20}$ Ališan 1890, p. 178 and facsimile, fig. 69. 
Klingons, battle the heroes of the American television and cinematic science fiction series "Star Trek"; and one of the writers of the programs, a linguist, devised a cacophonic, complete - and complex - Klingon language that role-players have adopted and learned. ${ }^{21}$ The particular activities, concerns, and values of a subculture spawn an argot; and it seems the reverse is true, as well, so that an invented language becomes a tool for the creation of an imaginary culture to surround it. Thus, mild-mannered American speakers of Klingon can escape with their hobby from the ubiquitous banalities of "Have a nice day," "Thank you for caring," and so on into a distant civilization that possesses very little in the way of phatic communication, ${ }^{22}$ its only form of greeting being the brusque "What do you want?" My favorite Klingon proverb is "Revenge is the best revenge." Typical paradigmatic sentences in the Klingon primer include "They are searching for the enemy in order to kill him," "I don't care," and "That helmet suits you." ${ }^{23}$ In a way, intergalactic Klingon brings one back, the long way, to the Caucasus; for its inventor, Marc Okrand - as I am informed by my learned Kartvelologist friend Michael Grossman of Widener Library - was inspired by Georgian phonology and idiom: the familiar salutation Gamarjoba! means, literally, "Victory!", not Hello. Klingon proper names such as Kang, Kor, and Torg sound pleasingly brusque to Americans imagining themselves a bit more macho than they are; but such names would not sound outlandish to Armenian ears, attuned to Xorenac 'i's Tork' the Ugly (anget). It will be seen that the supposed sounds of foreignness shaped Rंuštuni, as well.

In contrast to the harsh tones of Klingon one may cite another invented language, J.R.R. Tolkien's Sindarin, the speech of the delicate and poetic elves, which is as euphonious as Klingon is jarring, and as sweetly eirenic as Klingon is fractious. Typical expressions include "pools of golden water" (loeg ningloron) and "silver shining tree" (galathilion). Even the battle cry Lacho calad! Drego morn! ("Flame light! Flee night!") has some of the bromide undertaste of such saws as "Better to light a candle than curse the darkness." ${ }^{24}$ Esperanto, to be examined presently, is a pleasant sounding tongue, a bit like Italian to the ear. That measured euphony may be one reason it won out over another planned language, the harsh Volapük, which had been its principal competitor in the $19^{\text {th }}$ century arena. The invented language we are presently to examine from an Armenian MS had a script invented for it and as a substitution cipher for magic spells in Armenian; and

\footnotetext{
${ }^{21}$ One might find this material unsuitable to a scholarly paper; but I found out long ago that a number of my Harvard colleagues, superb philologists, are unabashed Trekkiesfans of Star Trek. Others enjoy the Dune books, with their generous helpings of Arabic. And I offer a course on H.P. Lovecraft, the American writer of horror stories, who also invented languages and drew material from ancient ones, much as his precursor Edgar Allen Poe did in The Narrative of Arthur Gordon Pym. An abridged version of the latter, translated most likely from the French of Baudelaire by one "H.E.V.C " " into Western Armenian, was published by the Vienna Mekhitarists in 1857: Nandugedc' $i$ Art'ur Korton Bimin pataharnero.

${ }^{22}$ By "phatic" I mean, following Everett 2008, those aspects of language that convey no information but serve rather to maintain social channels.

${ }^{23}$ See Okrand 1985 [1992].

${ }^{24}$ Salo 2004, pp. 103, 183, 213.
} 
Tolkien used both Runic characters and an elegant cursive like old Irish book hand for his invented Sindarin. He also loved magic: in what corner of the world is the wizard Gandalf's name not known?

Some invented languages in fiction are used to reflect the aspects of an imagined utopian or dystopian social order. George Orwell's totalitarian Newspeak in the novel 1984, a parody of Soviet and Nazi perversions of Russian and German, has given us "unpersons", "thought crimes", and a number of other neologisms that are sadly still usable long after the chronological year 1984 has receded into the past; whilst the Pravic of Ursula Le Guin's anarchist planet in The Dispossessed reflects its Edenic surroundings by lacking any possessive pronouns. The Sapir-Whorf hypothesis holds that the thoiught of which a person is capable is circumscribed and determined to a degree by the native language he speaks. Though the theory has not gained general acceptance and is most strongly opposed by the Chomskian school, Orwell seems to have toyed with it. In 1984 the secret police interrogator O'Brien remarks contentedly to his victim Winston Smith, the hapless protagonist, that in time Newspeak will so mold and limit human perception that thought crime, i.e., dissidence, will be impossible. Aklo, the name for a language of witchcraft in Arthur Machen's novella The White People (1899) was adopted by the American writer of horror fantasy, H.P. Lovecraft, as the dark speech of his evil cultists. And most recently Alan Moore in The Courtyard presents Aklo, in a sort of Whorfian riff, as a wholly unhuman language that alters fundamentally the perceptions and moral capabilities and judgments of those who learn it, destroying their humanity. ${ }^{25}$

Yet another sort of invented language altogether is the kind intended to be the very opposite of secret - the planned international language. There are two kinds: the $a$ priori type, with an entirely arbitrary and artificial vocabulary meant either to make the categorization of thought more rational or to put all learners on a level playing field, or the a posteriori kind - a language based on roots and endings culled from natural languages. Esperanto, invented by Ludwik Zamenhof (1859-1917), a Jewish oculist from Bialystok, is of the latter sort. Its inventor, a witness to the anti-Semitism and pogroms in the Pale of Settlement of the Russian Empire, hoped with his internacia lingvo to promote world peace through mutual understanding, generally, and to eradicate Jewhatred in particular. In 1887 he published at Warsaw in Russian his booklet outlining the rules and lexicon of his new language. ${ }^{26}$ It is interesting to observe that Zamenhof's contemporary and countryman, Eliezer Ben Yehuda, championed another sort of invented language (in a sense) - Modern Hebrew - after reading in Russian translation George

\footnotetext{
${ }^{25}$ Rogers 2011.

${ }^{26}$ Given the human character, it is a conundrum how a universal language could ameliorate matters. In a popular science fiction novel the mild-mannered English survivor of the destruction of planet Earth, adrift in outer space, is enabled to understand diatribes in the non-human Vogon language - and, worse, Vogon poetry - by sticking a Babel fish in his ear. Adams 2005, p. 60, comments: "the poor Babel fish, by effectively removing all barriers to communication between different races and cultures, has caused more and bloodier wars than anything else in the history of creation." So it might seem, in Adams' cosmos at least, a good job that God knocked the tower down.
} 
Eliot's novel, Daniel Deronda, on a Jew who resolves to revive his ancestral tongue in its homeland. Ben Yehuda emigrated to the Ottoman-ruled land of Israel in 1882, where his descendants still flourish and the language he revived is the native tongue of some seven and a half million citizens of a successful, democratic modern country. Zamenhof and his family, though sympathetic to Zionism, remained in Warsaw: his daughter Lidia (b. 1904) helped to lead the Esperanto movement after his death and embraced also the universalist Baha'i religion. Zamenhof himself had created a kind of universal ethical religion, Hillelismo (after the first-century Jewish sage Hillel), which he later renamed Homaranismo, which was to exist parallel to older and separate faiths as a way to remind people of their common humanity.

Hitler, who was anything but enamored of internationalism, humanism, and universalism, singled out Esperanto for attack in Mein Kampf as part of an imagined Jewish conspiracy; ${ }^{27}$ and his henchman Reinhard Heydrich made special efforts to ensure that the Nazi régime suppressed the language. He also compiled lists of Esperantists for arrest and execution. Zamenhof's study and library were destroyed during the German terror bombing of Warsaw in September 1939. Most members of the Zamenhof family were shot in Nazi prisons soon after, or gassed at Treblinka during the liquidation in 1942 of the Warsaw Ghetto. In considering the contrasting fortunes of the Ben Yehuda and Zamenhof clans, one thinks of the comparably parallel fates of two Jewish scholars from ostensibly civilized Germany: Gershom Scholem, an ardent Zionist, focused his studies on Judaica, emigrated to Israel after World War I, and embarked upon a career of many decades at the young Hebrew University of Jerusalem. Scholem's close friend Walter Benjamin, a universalist whose scholarship was of a correspondingly broader, socialisthumanist character, elected to remain in Europe and died in the Hitler era. One might conclude that the language called "One who hopes" is based upon a hope that is quixotically vain. Yet the language lives, and the number of speakers may be as large as some three million worldwide. Another estimate is but half a million, but even that figure is a thousand times the combined number of all other speakers of all other invented languages. There are still congresses of Esperantists in many countries around the globe, and one Esperantophone rock musician speaks it as a mother tongue alongside the natural language of his native country, Denmark. ${ }^{28}$ Esperanto has evolved the forms of a true living language: it has slang (e.g., krokodili, "to speak a national language in a setting when one should be speaking Esperanto"), obscenity and vulgarity (pisi, "to piss"; fiki, "to fuck"; kaldu "scram" from kuru al la Diablo "go to the devil"; and fikumin, "fuck off"), and new idiomatic constructions based upon its morphological peculiarities (-end-

\footnotetext{
${ }^{27}$ Mein Kampf is today a bestseller in Arabic and other translations throughout the Islamic world, along with the fictitious Protocols of the Elders of Zion. Esperanto is not popular there, although in the early $20^{\text {th }}$ century the Iranian Baha'i leaders encouraged its study and use. There are about 500 Esperantists in Israel, according to a friend; and Jerusalem has a Zamenhof Street. Michael Chabon, an American writer, imagined the counterfactual history of a temporary, Yiddish-speaking Jewish state in Sitka, Alaska in his novel The Yiddish Policemen's Union (2007). The action begins, appropriately, at the Zamenhof Hotel.

${ }^{28}$ See Okrent 2010 for a general survey of Esperanto, Klingon, etc.
} 
"which has to be" + pres. verbal ending > endas "is necessary"; kafumi, "to relax with friends over coffee", verbal inf. based on "coffee" with -um-infix). ${ }^{29}$ One member of the founding family, Zamenhof's grandson Ludovic, survived World War II, and addressed an Esperantist congress at Mainz in 1958. Delegates were nervous about what he might say, in Germany. But these were his words: "It has been a tradition in former Congresses, especially those before the war, when the Zamenhof family was in the literal sense numerous, that some member of the family should greet the Congress in the name of the family. I myself have had the honor of doing this several times... Today I should like to make a change, and instead of greeting you in the name of the Zamenhof family, I would like to greet you all, gathered together in this Congress, as the great family of Zamenhof in the literal sense of the word." ${ }^{30}$ It is hard not to respect an undertaking that engenders such perseverance and nobility of spirit, and one reflects that the Esperantists may well be among the redeemers of the honor of the human species, and not the losers.

There is the most interesting case of a little-known a priori universal language invented by an Armenian. Karapet T'onkərean (Tenger, Tingir, nom de plume $\mathrm{Tg}(\mathrm{h})$ ransar, 1754-1808), son of Grigor Hoca, a member of the aristocratic Armenian amira class of Constantinople, sired three boys and one girl. The eldest, Petros (Western Arm. Bedros), was born to his mother Mariam on 3 Sept. 1799 and at the age of twelve was enrolled as an acolyte of the Armenian Catholic seminary of the Mxit'arists (Ger. Mechitharisten) at Vienna. Ordained on 1 Nov. 1818, he returned to Constantinople but left for Bucharest in 1828 following the persecution of the Armenian Catholics of the capital by the Armenian Patriarchate. He then went to Vienna and Rome, gave up holy orders, and in 1844 settled in the wealthy suburb of Boudja (Tk. Buca) near Smyrna (Izmir). He had studied by then Greek, Latin, Arabic, Persian, Italian, English, French, and Sanskrit, besides Turkish, German, and, of course, the Classical dialect of his native Armenian. A few years later his well-to-do family built him a fine stone house on a hill at Aspra Khōmata ("White Lands"), where he labored to invent the vocabulary, script, and grammar of Seh-lerai, whose name means "universal language" (hamašxarhayin lezu; it is mentioned with various other spellings, including Sahleray and Sehlerai). He published an $\mathrm{ABC}$ of the language at Smyrna in 1864: the script he invented for it consists of a complex system of 19 consonantal characters to which various additional marks are added for the purpose of voicing or devoicing; a vertical bar signifies the place of a vowel, and smaller marks are added for the 12 vowels (these include Armenian and French diphthongs). (See Plates 8-11.) Bedros composed poems in his new language; and his disciples read these in French translation. In his alphabet he engraved on a plaque that he hung out over his house door the Seh-lerai word Ayzeratand (or Ayzeradant if the word is to be read in W. Arm.), that is, "Temple of Wisdom" (tačar imastut"ean) in his new language. Although the name of Bedros' Mozartian Weisheitstempel is polysyllabic and decidedly Irano-Armenian in feel, from the one existing sentence in Seh-lerai it would seem its inventor aimed at a monosyllabic system, comparable perhaps to the

\footnotetext{
${ }^{29}$ Schubert 1989, pp. 134-146, 204.

${ }^{30}$ See Boulton 1960, p. 217; on Zamenhof's daughter, her Baha'i ties, and her fate, see Heller 1985.
} 
planned, a priori language of Gabriel de Foigny (La Terre australe connue, 1676). ${ }^{31}$ The name $\operatorname{Tg}(\mathrm{h})$ ransar sounds rather like an Armenian compound of Tigran (the name of the great Artaxiad king, r. 95-56 BC) and -sar, "head, summit", but it apparently means noēkē kinēsis, "mental motion" in Seh-lerai.

Bedros was widely loved and respected for his kindness and learning. One day in 1881, feeling death approaching, he lay down on a couch prepared in his temple: his disciples found his body at peace on the morn. He had been in life a strict vegetarian, so one has the impression that the language accompanied a mystical or humanitarian and universalistic teaching, an invented culture like the one Zamenhof was to conceive later on. In the September and October 1921 issues of the Greek Esperantist journal Bizantio, Dr. Anakreōn Stamatiadēs (Eng. Stamatiadis, 1 Sept. 1868-24 Jul. 1964), a prominent physician and serious Esperantist (his Greek-Esperanto dictionary is standard and has been reprinted in recent years), published in Greek and Esperanto a summary of Bedros' little booklet on the script he had invented for his language. The grammar and dictionary of Seh-lerai, though prepared for publication, seem never to have been printed. That was the year of the demise of the postwar Turkish administration, that had, even halfheartedly, prosecuted the perpetrators of the Armenian Genocide; and in 1922 the invading army of Mustafa Kemal ("Atatürk") burned Smyrna to the ground and massacred or drove its Greek and Armenian Christian populations into the sea. The cosmopolitan culture and hopes of Bedros Tenger died in Turkey perhaps even more cruelly than did those of Zamenhof; for as we have seen, Esperanto rose from the ashes, whilst Seh-lerai was very nearly relegated to oblivion. ${ }^{32}$ The hill where Bedros' Temple

${ }^{31}$ See Eco 1998, pp. 77-95.

${ }^{32}$ Ayvazean 1893, pp. 91-95; Pōłosean 1951, pp. 34-39; and Russell 2010. Albani and Buonarroti 1994, p. 371 s.v. Sehlerai, report that the inventor of Seh-lerai published at Smyrna in 1864 under the pseudonym Tghransar (with - $g h$ - in Latin letters and gamma in Greek) a description of his language, but misspell the name of the book. Its correct title is Ans hailanzar ou Alpha-Gnomonomic de Sehlerai. They provide a sample sentence with translation: Rum shai yran bes lerai vom, shaiz il le sam lerai iun sim, mim serai vam shaiz il le som "Nel mondo sarà preferita una lingua scientifica unica à numerose lingue con una scienza unica." Drezen 1967, p. 61, has this notice: La libro de Tgransar portis la nomon "Alphabetarion Ansailanzar Sahlerai" kaj estis eldonita en Smyrna. La eldonjaro de la libro ne estas konata, sed lau la havataj informoj ô $i$ estis publikigita en ćiu okazo ne pli malfrue ol ce la fino de la XVIII jarzento. ("Tgransar's book bore the name Alphabetarion Ansailanzar Sahlerai and was published at Smyrna. The date of publication of the book is not known, but according to the information we possess it was published at any event no later than the end of the $18^{\text {th }}$ century." [Tr. by J.R.R.]) But that would place the invention of the language at or before the date of Bedros' birth; and this erroneous notice seems to be the source of a similar assertion by the linguist Mario Pei in his One Language for the World (New York: Biblo and Tannen, 1968, p. 147) - that Sehlerai (as he calls it) was invented around 1800 but published in 1921. The latter date is erroneous as well and must refer to the date of Stamatiadis' Esperanto translation in Bizantio (Tgransar 1921). A copy of Tgransar's book, perhaps the only one in existence, was given in 1928 to Aram Andonian, the first librarian of the AGBU Nubarian Library 
of Wisdom once stood is called to this day Tingır tepe ("hill"), and statues of the Persian Sufi poet, theologian, and saint Mevlana Jalāl al-Dīn Rūmī stand at the summit. (See Plate 12.)

There is yet another category of invented language: the hypothetical one based on mathematical ideas that can overcome the normal boundaries of rational thought as expressed by means of natural languages. In his novella Youth Without Youth the Romanian scholar of Oriental languages and comparative religions Mircea Eliade imagines a character attempting to discover the source of all language. Despairing and alone, at seventy, he travels from his hometown to the capital, Bucharest, to end his life. It is Easter Sunday. He is struck by lightning and rejuvenated, endowed with the preternatural ability to learn a new language almost instantaneously. He begins to keep his diary, partly for his own cognitive purposes and partly for secrecy, in an invented language that can transcend both spatial differentiation and temporal sequentiality. To do this it employs the teoria ensamblurilor (Romanian, "theory of aggregates"), a semantic refinement of set theory allowing for a set not located in a time-space sequence. ${ }^{33}$ So Eliade's character can express logically in his language concepts that can be phrased within space-time only as paradoxes or not at all. One is reminded here of a reverse process in language - that of endowing a simple natural word with greatly expanded, trans-rational semantic content - that happened in actual history: the Russian Orthodox mystical practitioners of imiaslavie "Name-worship" declared that the name of God was, simply, God (i.e., any arbitrary name of God in any language was His ineffable one); and mathematicians inspired by them conceived of God as the temporally and spatially paradoxical but nonetheless conceivable set of all sets, i.e., a set including itself. ${ }^{34}$ Shortly after citing Eliade's assertion in another work, Myth and Reality, that the purpose of mythic ritual is to overcome time, the American science-fiction writer Philip K. Dick in his novel Valis has his protagonist start thinking in a language of two thousand years ago - in a properly Eliadian moment of linguistic and cognitive transcendence he then

at Paris (and author of Mec očirz ["The Great Crime"], one of the first histories of the Armenian Genocide): the present director, Dr. Raymond Kevorkian, has very kindly provided to me a scan of it, which I plan to reprint with a study of its contents, which include comments on the phonology of Armenian, Hebrew, Russian, and Arabic (with characters in the original typefaces of these languages). I have forwarded the scan to the Esperanto divisions of the Austrian National Library at Vienna, the British Library at London, the Library of Congress at Washington, DC, and the Widener Library at Harvard; so this extremely rare and unusual work, which, it seems, has not been seen for some ninety years, can now be widely consulted. I am grateful to my colleague Professor Valentina Calzolari of the University of Geneva for her suggestion that I contact the Nubar Library. Vağarşag Seropyan (Vałaršak Serop“ean) published a biographical article with useful references, "Tingıryan, Bedros", in the Yaşamları ve yapıtlarıla Osmanlilar ansiklopedisi ["Encyclopedia of the lives and deeds of the Ottomans"], Istanbul, 1999, vol. 2, p. 624.

${ }^{33}$ Eliade 1988, p. 104; and Burge 1977.

${ }^{34}$ Graham and Kantor 2009. I wish to express my gratitude to my esteemed colleague and friend Prof. Loren Graham for the gift of his stimulating and illuminating book. 
"saw the ancient world appropriate to that language" ${ }^{35}$ Eliade, a committed fascist, gave the hypothetical language of his lightning-struck, immortal superman an otherworldly, archetypal, even mythopoetic quality. James Joyce, a contemporary whose views could scarcely be more different than Eliade's, wrote his hymn to a plain, mortal Irishman: Finnegan's Wake is an alliterative, encyclopedic deluge of argots and languages and word games that critics of the 1930s called an "Esperanto of the unconscious", "an interracial language... to express the collective inner vision of mankind." Invented languages and argots crop up in the flood of the text: "Volapucky" (after Volapük), "florilingua", "sheltafocal" (cf. the Irish argot called Shelta, which Joyce studied). ${ }^{36}$

\section{The St. Petersburg MANUSCRIPT}

And so we come to the Armenian MS with its invented language and three invented ciphers. (See Plates 1-6.) The complete description of St. Petersburg Or. Inst. MS A 29 by Prof. Yuzbashian is translated in the appendix. He mentions the three Armenian cryptograms therein: there are keys in the MS to all three; but only the third recorded, henceforth to be called the Third Script, is actually employed in the writing of texts. None of the ciphers is known to exist anywhere else; so they attracted the attention of A.G. Abrahamyan, who provides all three keys in a description of the MS in his work on Armenian cryptography, with a reference to the 1894 publication of Ałaneanc '. ${ }^{37}$ Abrahamyan does not seem to have examined the MS, and relied upon copies of the cipher keys made by $\mathrm{P}($ aruyr) Muradyan at Leningrad. The first cipher, on fol. 1a (not 37b, pace Abrahamyan), is based upon the third, on fol. 44a. The second, on fol. 37b, consists of letters imitative of the Devanagari script without the upper horizontal bar, but so complex and elaborate as to be quite impractical. The third, which is spare and elegant, was intended for use in writing an "alternative" (Arm. aylakan) language to which the copyist gives the name $\dot{r} u s ̌ t u n i$. But except for three words immediately following the key, it is used in the MS only for encrypting Armenian - for the most part, magical spells and incantations. These are deciphered, transcribed, translated, and annotated in the appendix: they have not been published before.

All three are simple substitution ciphers, and the keys follow the order of the Armenian alphabet, with the additional ligature or digraph for ew ("and") and the characters for the letters $\bar{o}$ and $f$ (in the Armenian alphabet these were added in the Middle Ages to the original 36 letters of Maštoc'). Abrahamyan writes of the MS, "About ten pages of text of magico-astrological [Arm. axtarakan] content are encrypted using the

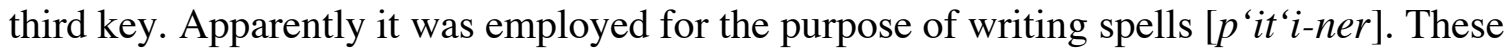
are of no historical value so we consider it superfluous to provide numerous examples. It is not difficult to observe that the three cryptograms cited are secret scripts made of complex lines and could not be widely employed. So it was. Except for the Leningrad MS considered here, no other text encrypted with these ciphers has been discovered." ${ }^{38}$ It

${ }^{35}$ Dick 2011, p. 39.

${ }^{36}$ Schotter 2010, pp. 91, 93.

${ }^{37}$ Abrahamyan 1978, pp. 158-159.

${ }^{38}$ Abrahamyan 1978, p. 159. 
is manifestly untrue that the Third Script is complex or unusable. Quite to the contrary, close examination of the MS shows that the copyist wrote it swiftly, fluently, and with a delicate and confident calligraphic flare. Nor is it true, except in the most literal sense, that the use of the Third Script was confined to MS A 29: the cardboard of the inner cover at the beginning of the MS is made of discarded bits of text, mainly jottings it would seem, in Georgian, in standard Mesropian Armenian, and in the Third Script and Armenian language, all most likely in our anonymous author's hand. One scrap reads: meraw ibrew amac " wat'snic " [sic!] nasur k'ałak'i or ew asi aristotel "He who is called also Aristotle died around the age of sixty years in the city of *nasur." Another scrap in mixed Third Script and Mesropian is in Armenian too narrow to yield any entire word excerpt catr ("laughter, ridicule"). It would seem that our writer, if indeed he was the inventor of his cipher, had used it for various purposes in various places over some, probably many, years. Though he did not create a universal language to be written with it, as Bedros Tenger did at Smyrna a few generations later, or a mythology to embody it, as Tolkien did a few generations after that, he was interested in magic and mythological lore (see the text on the hamasp 'iwr flower) and he did create an a priori language with the intention of learned application (as well as obscenity!). His script is based largely upon the forms of the letters of the Armenian and Georgian alphabets, in the latter case particularly the nuskhuri, or minuscule hand, of the khutsuri, i.e., Classical Georgian script, which is itself in its origins a modification by St. Mesrop Maštoc' of the Armenian erkat "agir (uncial, lit. "iron letter") alphabet he had devised at the beginning of the fifth century. ${ }^{39}$ Another, more famous countryman and contemporary of our scribe, hailed from Tiflis, the Georgian capital: the bard Sayat' Nova, who died in 1795 (three years after the stamp in our MS). The poet's devt'er or tetrak - the manuscript book of his own songs - is written in two alphabets, curvilinear Georgian mxedruli and the standard Armenian minuscule called bolorgir. But the latter is used for Sayat ' Nova's compositions in Tatar (i.e., Azeri Turkic), while the songs in Armenian are written in Georgian script. ${ }^{40}$ Page 103 of the devt' $e r$ mixes the Armenian and Georgian alphabets. ${ }^{41}$ Since the bard often employed Tatar, Armenian, Georgian, and Persian all together in a single song, it is not hard to imagine that the same sense of artistic play and interchange might have motivated his idiosyncratic manner of writing. So the mixture of Georgian and Armenian is, if anything, quite normal for the time and place.

\footnotetext{
${ }^{39}$ The Vita of the saint, Vark' Maštoc ' $i$, by his pupil Koriwn, mentions that Maštoc' devised alphabets for Armenian, Georgian, and Caucasian Albanian (Ałuan) - the first surviving MS in the latter, a palimpsest, was discovered and published nearly two decades ago by Alexidze and Mahé. On the Arm. alphabet, including the cipher called Ałuanic' gir, see Russell 1994 and 1994(b). For tables of the Georgian scripts see Fossey 1948, p. 180.

${ }^{40}$ It is curious that although Sayat' Nova had scribal abilities in Armenian - towards the end of his life he copied a MS of the Narek prayer-book at the monastery of Sanahinhis Mesropian letters are rather choppy and awkward, whilst his mxedruli shows a fluid and serendipitous calligraphic ease. And it is that script he chose to write his native, Armenian tongue. It would seem that in the consciousness of the Armenians in Georgia, the Georgian alphabet was not foreign.

${ }^{41}$ C'ugaszyan 1963.
} 
The order of the letters of the Third Script is the same as that of standard Armenian. B is a combination of Arm. $\mathrm{p}$ and $\mathrm{b} ; \mathrm{Z}$, an extended form of $\mathrm{z} ; \overline{\mathrm{E}}$ resembles the $\overline{\mathrm{e}}$ of an earlier and then still extant and flourishing Armenian cryptogram called "Ałuan" or "dove-script" whose extensive use I have discussed elsewhere; (see Plate 7) ${ }^{42}$ 马 may be compared to "Ałuan" ə; $\mathrm{T}^{6}$ is a modification of $\mathrm{t}^{\text {"; }} \mathrm{I}$ is an upside-down, reversed nusxuri $\mathrm{i}$; $\mathrm{L}$ is a modification of 1 ; $\mathrm{C}$ may be a form of "Ałuan" c; $\mathrm{K}$ is based on Georgian $\mathrm{k}$; $\mathrm{J}$ is Arm. $\mathrm{j}$ with a bar added; $€$ is a doubled $ł$; $\check{\mathrm{C}}$ is the preceding symbol upside-down; $\mathrm{M}$ is a flipped-over nusxuri $\mathrm{m}$; $\mathrm{Y}$ is an "Ałuan" $\mathrm{y}$ on its side; $\breve{\mathrm{S}}$ is a shortened form of the preceding character for $\mathrm{n}$; $\mathrm{O}$ is based on nusxuri $\mathrm{o}$; $\check{\mathrm{C}}^{6}$ seems to be a lower-case $\check{c}^{`}$ on its side; $\mathrm{P}$ is Arm. lower-case $\mathrm{p}$ without its long vertical bar; $\breve{\mathrm{j}}$ is based on nusxuri $\mathrm{d} ; \dot{\mathrm{R}}$ and $\mathrm{S}$ are reversed forms of each other; $\mathrm{V}$ is an elaborated Arm. $\mathrm{v}$; and $\mathrm{F}$ is based on nusxuri $\mathrm{r}$. $\mathrm{T}$ is a lower-case Latin $\mathrm{t}$ or cruciform. $\mathrm{K}^{\text {' }}$ the $36^{\text {th }}$ letter of Armenian, the last in the classical alphabet, is dignified by the Chi-Rho chrismon to signify Christ's presence as Omega (last letter) as well as first, in the standard script. In the Third Script it is a circle, the ancient symbol of perfection. ${ }^{43}$

As Prof. Yuzbashian noted in his description of the MS, there is a table of the letters of the Russian alphabet, with the Old Slavonic names of each letter ( $A z, B u k i$, etc.), towards the end of MS A 29. This reminds one that it belonged to the period in which Russia was becoming the dominant power in the Transcaucasus and immediately preceding the liberation in 1828 by Russia of the Khanates of Erevan and Nakhichevan and other areas - the ancient heart of eastern Armenia including the plain of Ararat, the sacred mountain itself, and the holy city Echmiadzin. Down to the mid- $18^{\text {th }}$ century the Armenian community at New Julfa of Isfahan, with its far-flung trading network, had been the center of the nation's commercial and cultural life outside the domains of the

\footnotetext{
${ }^{42}$ See Russell 2010. At Erevan I had the opportunity to study Matenadaran 6644, which is the oldest and richest MS for texts encoded in the "Ałuan" cipher, which the author of the MS calls gawazanay gir, "the script of the scepter/crozier". It is, as one might expect, eclectic and with a leaning towards the occult. There are texts on astrology, on other cryptograms (notably, on fol. 132v., the very old one consisting of vertical lines and dots that is found even on Cross stones and may be derived from the appearance of Urartean cuneiform inscriptions on steles Armenians saw and sometimes co-opted, indeed, as $x a \check{c}^{\prime} k$ 'ars), and (fols. 107v.-108v.) on the numerological significance of the Mesropian script: ew zn kat(a)r(ea)l t'iw e, isk vec 'ic "vec ' $n l z, \bar{e}$ "and $z$ [the sixth letter] is a perfect number; and six times six is XXXVI" - the Armenian alphabet has 36 letters, and the magical text Vec" hazareak ("The Book of the Six Thousand") plays on its Pythagorean symbolism. See Russell 2013(b).

${ }^{43}$ It is noteworthy that the $36^{\text {th }}$ and final letter of the Tengwar table of letters invented by Tolkien for Elvish and other languages of Middle Earth is likewise a circle - of anomalous shape when compared to the rest (Tolkien 1955, p. 1092). It is unlikely this is merely fortuitous and without symbolic purpose; for Tolkien was a meticulous calligrapher from early childhood, and employed a hand based on $10^{\text {th }}$ - and $11^{\text {th }}$-century models for both his English and his invented Tengwar (see Hammond and Scull 1995, pp. 201-202).
} 
Ottoman Sultan; and Julfa Armenians shifted some of the balance of trade to the Transcaucasus corridor. They also forged links with the Russian Empire: in the $17^{\text {th }}$ century Armenians had become established at Astrakhan on the north shore of the Caspian. With commercial expansion came emancipatory political activism.

The dawn of the $18^{\text {th }}$ century saw the mission of the Armenian Israyēl Ōri to the court of Peter I the Great (1682-1725) to plead for Russian liberation of the Christians of Armenia. Following his successful campaigns against the Swedes, the Tsar, urged on by the petitions of the Armenian meliks (hereditary landed nobility, heirs to the ancient naxarar-doms) of Arc'ax (Karabagh), crossed the river Terek in the North Caucasus in 1722. The savage repression of non-Muslims by the Iranian Nāder Šăh in the 1740s signaled the end for the Armenians of the power of the New Julfa global network, and the need for political protection by a Christian power. Yet the Russian southward advance was very gradual until Catherine II the Great (1762-1796) pressed Russian claims and concluded an alliance with the Georgian king Erekle II (1762-1798). In 1795 the Persian Qajars sacked Tiflis, the Russians retreated, then advanced once more and annexed Georgia and abolished its native monarchy in 1801. Between 1809 and 1812 Russia continued to absorb territory to the south, including the important Armenian center of Akhalkalaki. ${ }^{44}$ Though the Armenian Church cautiously avoided political entanglements, whether in overtures to Russia or rebellion against the Muslim powers, the gifted Catholicos Simeon of Erevan (1763-1780) took steps to consolidate the authority of Echmiadzin as the Mother See of the Church, reducing the centrifugal authority of other jurisdictions and defending the integrity of Armenian landed and other properties on the plain of Ararat and in the immediate vicinity of the holy city, from Muslim encroachment. But he still ordered that the pathbreaking manifesto calling for Armenian national liberation be burned. This was the Nor tetrak or koč" $i$ yordorak ("The New Pamphlet called Exhortation") of two New Julfa Armenians at Madras, Nersēs Bałramean and Yakob Šahamirean. ${ }^{45}$ MS A 29 bears the seal of one Grigor from 1792. So despite the lack of a colophon one can be quite confident that it was written in the late $18^{\text {th }}$ century, at a time when Armenians were using ciphers actively and often. The author lived in Georgia: there is Georgian writing in the cartonnage and the shapes of a number of the cipher characters are based on the Georgian nusxuri hand, as discussed earlier; and the table of the Cyrillic alphabet suggests the pounding hoofbeats of the Cossacks' mounts could be heard getting louder and louder.

Here is the discussion of the MS and its context, by Fr. Ałaneanc', in his chronicle of the history of the Armenian Church in the eighteenth century, in my translation and with my comments and elucidations in square brackets: ${ }^{46}$

"Till now only one sort of cryptogram is known. It is well known that during the clamor about the conflict of David and Daniel at the beginning of this century the parties of the

\footnotetext{
${ }^{44}$ See Bournoutian 1998, pp. 3-6.

${ }^{45}$ For a translation of the Jambi "Chamber" - a primary documentary source on the life and politics of the Ararat region in this period - see Bournoutian 2009.

${ }^{46}$ Ałaneanc' 1894, cols. 842-846, tr. from Armenian mine.
} 
two opposing Catholical sees had no other means available to them save to destroy each other's capabilities and so obtain victory. Fr. Nersēs of Aštarak [a village near Erevan], who was later to become Catholicos [supreme patriarch] of All Armenians, belonged to Daniel's party. The people of this party, in order to keep their correspondence secret, employed a form of cryptographic script in the place of Armenian when writing to each other. As some of their letters are preserved in the library of Holy Echmiadzin [holy see of the Armenian Apostolic Church, near Erevan], the late Abp. Gabriel Ayvazean succeeded in finding the key and reading them. Some of these were penned by the hand of Catholicos Daniel himself. Fr. Ayvazian's reading is mentioned in M. Msereanc', Patmut 'iwn kat"ułikosac" Ejmiacni ["History of the Catholicoi of Echmiadzin"] and in A. Eric'ean's Niwt'er Nersēs V-i kensagrut'ean ["Materials towards a Biography of Nersēs the Fifth"]. Thereafter an article authored by one "Miaban' ["Monk"] appeared in the January 1888 issue of Ararat in which the author, on grounds unknown to me, called the cipher 'Nersēsian', rejected Fr. Ayvazean's reading in its entirety, and claimed the honor of primary decipherment for himself. He supposed the cipher to have been devised by 'Nersēs V', though he advanced no proof of this. Scarcely two months had passed when in the April issue T'. Zak'arean, a student at Petersburg, who had studied at Echmiadzin during the tenure as principal of the late Abp. Ayvazean, published an article with a rather convincing factual demonstration that Ayvazean had read a number of the encoded letters for the first time long before, in 1868-1869; so the honor of priority belonged not to 'Monk' but to Abp. Gabriel. So much for our knowledge of Armenian cryptograms. But the present Memorial in our opinion sheds new light on the matter. One mahtesi [i.e., Arabic muqaddasi, an Armenian Christian who had made the pilgrimage to the "holy (city)" of Jerusalem] Yōnan, from Axalc'xa [an Armenian town in southern Georgia], and Simeon Catholicos in Holy Echmiadzin, corresponded in a similar cryptogram 'newly devised' as early as 23 July 1766 in order to conceal their dogged efforts in opposition to the spread of Catholicism. It is not known who invented this "newly contrived writing', but it is not hard to surmise that Simeon Catholicos, who could resort to many techniques with his intelligence and skill at contrivance, could have invented without difficulty such a cipher to suit his purposes. It is a fact at any rate that the cryptogram was invented before mahtesi Yōnan left Axalc'xa, since Simeon was already acquainted with the manner of its writing and was employing the same in his encrypted messages to Yōnan. One must assume, even as the usage of the phrase 'newly invented' indicates, that the cryptogram was entirely new, since it was employed for the sole purpose of keeping letters secret. One must infer from this that its existence was unknown to anybody else and Simeon could thus have invented it and taught it to mahtesi Yōnan, whom he dispatched with some instructions to Axalc'xa. But this is only a likely supposition and we are not prepared at this point to assert it as fact, since we do not possess even one of those letters that might allow us to shape an idea about the cipher. We do not know it or what it was like. In the time of the Catholicosate of Simeon, Catholicos Daniel was already a fairly well known cleric. The man of letters Melk'ised in his Čar govut'ean goveleac " ["Oration of praise of the praiseworthy"] devotes an entire chapter of praise to him... Fr. Nersēs, who in his own words (Amenayn Hayoc" kat "utikosner XIX darum ["Catholicoi of All Armenians in the $19^{\text {th }}$ Century"], by A. Eric'ean, Tiflis, 1892) was in 1816 already 46 years of age, studied in the days of the Catholicate of Simeon at Holy Echmiadzin in the school newly erected by Simeon 
himself. So the two of them, both Daniel and Nersēs especially - for the latter spent all his childhood and youth in the monastery of Echmiadzin - could have been acquainted with the 'Simonian cryptogram'. It would not be improper or entirely without foundation to consider that Nersēs might thus have used the cryptographic symbols of Simeon Catholicos. In the expectation that the future will enlighten us about the situation by revealing the encrypted correspondence of Simeon Catholicos and mahtesi Yōhan, and to satisfy the interest of philologists, we present here some information of importance to Armenian cryptography. These days, by fortunate circumstance, we acquired a few manuscripts, one of which is of particular importance in this regard. It is a booklet [Arm. grk'oyk] of modern date, in our estimation a product of the end of the last century [i.e., the $18^{\text {th }}$ century] or the beginning of this, written by a fairly unskilled writer in an ugly notary hand, on crude paper, half of the book yellowish and half of it blue. [This is A 29.] It contains various short writings but the most interesting of its contents are the Armenian cryptograms. The book is undated and has no colophon, and it is not known who the author was. In only one place, on fol. 45, in minuscule [Arm. bolorgir], are these words: $i$ metsamac jahankal yakobē ew grigorē ["by the sinful torchbearers Yakob and Grigor"]. Whether these names belong to the two poems adjacent to the line, which form an acrostic of both names, or to the whole book, is not known. The book contains three ciphers. 1. On the very first page of the book is a cipher $\mathrm{ABC}$ in the order of the Armenian alphabet, with the Armenian plaintext written above each character. At the head of the ABC, in the letters of another type of cipher [the Third Script, actually], is inscribed this heading: ayl imn kerp tark" ["letters of another type"]; and below, in the letters of both cipher types, [i.e., both this one and the Third Script], is written, nōtr tark en aysokik' ["these are notary letters"]. The letters are employed to express one thoughts in Armenian words that are concealed. The first system is not used at all in the book. 2. On page 75 of the book is a second cryptographic alphabet in Armenian order, number, and equivalence. But these letters have their own special language. On the following page [fol. 37b] the names of the letters of the cipher are given: ah, bof, gam, doh, eh, zêfa, $\bar{e} s$, sp', t'ov, žimla, in, lin, xōs, crva, kuk, hōvt'a, jul, tway, čič, mirvat', yi, narut', šō, obi, $\check{c}^{\prime} u k^{\prime}$, prav, Jom, reli, sov, vrxa, trōi, rōsi, c'un, wrēe, p'ap', k'rōm, ewta [for the diphthong/digraph ew], orri, frasi. Immediately beneath these is written, Aylakan lezu or ew asi ruštuni ["An alternative language which is also called ruštuni": the word aylakan, which I translate "alternative" and Yuzbashian in his catalogue seems to have understood as uslovnyi, Rus. "provisional, conditional, hypothetical", is not standard Armenian and it is not clear whether by it the writer of the MS meant a hypothetical, invented language of his own or one he has learned in which other words are substituted for Armenian]. It is unknown why this language is called ruštuni. We do not know whether this was the inventor's name or whether he had some connection to Řštunik' [the region on the southern shore of Lake Van, directly north of Moks] — and the book affords no idea. Thereafter follows a fourteen-page glossary of the language, which we present here for those interested. This second type of cipher is not used in the book either, except for a few words, which were erased by a later hand and can be read only with difficulty. All the letters of the $\mathrm{ABC}$ were likewise erased, and we were barely able, with the assistance of learned analysts, to read them. ${ }^{47} 3$. On the reverse side of the glossary, page 90 of the

${ }^{47}$ This second script looks a bit like an ersatz Devanagari shorn of the top bar most letters 
book, is inscribed the $\mathrm{ABC}$ of a third cipher, which has this title: ays lezui tark's ays $\bar{e}$ kerp aybubēnk' ["These are the letters of this language, the shape of the ABC's" by which one should, presumably, understand the $\dot{r} u s ̌ t u n i$ language immediately preceding]. And below in this cipher, with the Armenian letter equivalents beneath, is written, $t^{\prime}$ 'agaworesc' $\bar{e}$ Têr yawitean ["May the Lord reign eternal"], and ayl ews bark' ["some more, other words", i.e., in ruštuni]: milduvēwk' tramabanut' $i w n /$ sēlduvēwk' čartasanut 'iwn/ ǰêmsavēwk' k'erakanut 'iwn ["milduvēwk' logic/ sēlduvēwk' rhetoric/ jemsave $w k^{\prime}$ 'grammar"]. This ABC is employed thereafter, right to the end of the book, in many places for various medical and magical purposes, and for potions. We print the three cryptograms here with their Armenian equivalents. There is no further information about Armenian cryptography. In the newspaper Azgasēr ["Patriot"], edited by M[esrop]

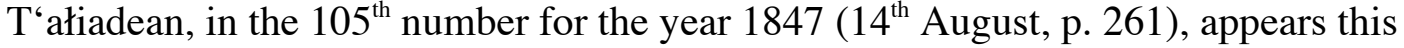
notice: 'In the list of MSS sent to us by the relatives of the Ënfiēcrians we read "The arhest grč "ut'ean ["scribal craft"] of Frs. Gēorg and Aristakēs", in which are contained some three hundred symbols.' We considered for a moment that those symbols might be cryptographic. But from subsequent investigation it became clear that this very MS volume had been acquired by the library of the Lazarev academy in Moscow and the symbols [Arm. nšanagrer] of Gēorg and Aristakēs are the same that the late M[krtič‘] Ėmin published in his translation of Movsēs Xorenac'i and that Is. Yarut'iwneanc' printed in his Hayoc" gir ["Armenian Writing"], and have no connection to cryptography."

Ałaneanc" alludes in the above discussion to two letters written in the "code of Nersēs of Aštarak" that were published in Ararat in 1888. It is appreciably different from the three ciphers of MS A 29 in the shape and style of the letters, though it is, again, a simple substitution cipher. Fr. Yovhannēs Karbec'i, who was to become Catholicos, wrote the first on 28 April 1801; Bp. Rot' ${ }^{'}$ eos, a supporter of Nersēs against his rival, Dawit', wrote the second. There is another letter in the cipher dated 26 January 1813 sent from Tiflis by Nahapet Aršakean to Fr. Nersēs: this one is of great historical interest as testimony to the epochal event of the previous year, 1812 - the capture of Moscow by Napoleon Bonaparte, the great fire, and the French retreat in winter from Russia:

"Here is the news. [Napoleon] Bonaparte [Pōnapōrtn] with 200,000 men departed and went away to his country. It is certain, what I write here. If you say they write or say otherwise it is empty or [newspaper? - Rus. gazeta, here Arm. $k^{\prime}$ azeti] writing. And this is the place for performing prayer [malepni, i.e., Rus. moleben'], as you know. He took 200 wagons of gold and silver from Moscow with him, and it seems there is yet to be a great battle in the winter. The day of this writing, a letter came from Galterē[w?]ski. They have joined battle with the $\check{s} \bar{a} h z \bar{a} d e h$ [Pers., "prince"], have captured the latter's entire

have; and the character for $m$ in particular is identical to the $m$ of present-day Gujarati, where the bar is lost. Sayat " Nova, the bard of Tiflis contemporary with our writer, may have traveled to India; travelers from northern India left graffiti at the "fire temple" of Baku; and in any case populous and well-to-do Armenian communities of merchants from New Julfa flourished in India in the late $18^{\text {th }}$ century. So it is quite possible for the inventor of the cipher to have seen a sample of Sanskritic script at some point. 
camp and there has been great slaughter, so that only the $\check{s} \bar{a} h z \bar{a} d e h$ got away, and they seized all his guns. This filth [? - attut 'iwn] was more than four times. I received a letter from Nakhichevan from the prelate Ōhan: they wrote of their displeasure and want to summon Fr. Grigor. And Galterewski broke his leg in the battle, so they will send a good doctor from here on the $27^{\text {th }}$ of the month, as well as reinforcements. They have taken Lank'aran [i.e., Lenkoran], Tališ, and $\mathrm{P}^{‘}$ arš. $"{ }^{\prime \prime}$

As we shall see presently, the itinerant felt-beaters of Moks, the region immediately south of R Řtunik', had a secret language. Since they traveled all over Armenian, perhaps the name of the ancient and fabled region north of their home mountains came to be associated with secret or invented speech generally. The invented Ruštuni language, known only from this one manuscript, is of the a priori type: the vocabulary is not derived from any known natural language and there seems to have been a conscious effort to make its phonology as different from that of Armenian as possible (there are over 130 occurrences, for instance, of the rare letter $\bar{o} ; \bar{e}$ is used word-internally with far greater frequency than in standard Armenian; and $f$ is also used far more often than in any dialect, literary or rural, of the language). But the phonemic character of the language is still Armenian, with variant voiced and unvoiced stops: both trōpēn and

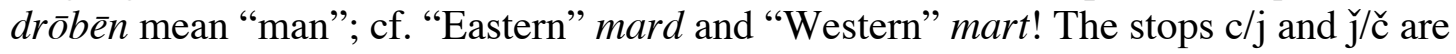
likewise interchangeable. The word count is approx. 250; but the selection of terms with invented equivalents seems to have been arbitrary, with the author flitting from one category to another, and enjoying plenty of naughty obscenities in between - there is nothing approximating the Swadesh list or other register of frequently used terms in human speech. A tourist on the planet Ruštunistān would not find the glossary very useful for many of his needs. The morphology is inconsistent but still observably based on Armenian. There is a gen. sg. $-i$, -in, or -vin, cf. Arm. $-i(n)$; gen. pl. $-r$; abl. sg. $-\bar{e} m$, cf. Arm. $-\bar{e}(n)$; inst. sg. $-y \bar{e}$; and loc. sg. $-i n \bar{o}$. As in Arm. there are possessive pronominal suffixes: $1 \mathrm{sg}$. $-i b ; 2 \mathrm{sg}$. $-n$. Abstract nouns are formed in -vewk' (cf. Clas. Arm. pl. $-k^{\prime}$ ) and $-\bar{e} t^{`} \bar{o} n$ (doubtless from Arm. $-u t^{\prime} i w n$ ). Influence of the Armenian assonance of the pair erkin and erkir, heaven and earth, may be reflected in the formation of rōšmēxe "earth", rōlve "world", and rōčki "heaven". Nim "outdoors" may be related to nimo "sun" (and note nimōfre, "he went out"). The relationship of $m \bar{e} v \bar{o} n$ "water" to mivat "drink!", or of sēmat" "apple" to semsay "pear" seems less the result of a conscious plan than of proximity - the words fell into categories the creator of Ruštuni was thinking about as he made them up. (Srôfit "bring!" for instance, is next to the semantically unrelated factitive verbs for "drink" - see below - which sound much the same, and are unrelated to mivat above.) One notes that the latter translates the simple Arm. arew; but for Arm. aregakn, a poetically marked compound term for the solar orb, the inventor has created an entirely unrelated word, ziwōtep. Verbs are formed on the Armenian pattern as well, though, again, the forms themselves are fanciful: pres. 1 pl. $\bar{o} t^{`}$; aor. 1 sg. $-t$, -lêf; aor. 2 sg. $-l \bar{e} t$; aor. 3 sg. $-t a$; imp. 2 sg. $-\bar{o}$; imp. 2 pl. $-\bar{o} t^{`} \bar{e}$;

\footnotetext{
${ }^{48}$ Abrahamyan 1978, pp. 167, 170-171. The person whose name is given as Galterewski (otherwise unknown) is most likely the Russian Colonel P.S. Kotliarevskii, one of the commanders who seized the fortress of Shah Bulagh in Karabagh in 1805 (See Bournoutian 1998, p. 132 n. 5).
} 
prohibitive imp. t'u- (e.g., srôfētōn "make sm. drink", t"usrêfēti "do not make sm. drink"). There is a past participle in $-(a) w l \bar{o}$, cf. perhaps Clas. Arm. -eal. This language is then a private game and not a particularly inventive one, without morphological departure from Armenian. But this indulgence in the pleasant sounds its inventor associated with alienness does at least give us a useful sense of what a native speaker of Armenian in the $18^{\text {th }}$ century thought his mother tongue did not sound like.

\section{The ARgOT OF THE FELt-BEATERS}

The invented language in MS A 29 is called $\dot{R} u s ̌ t u n i$; so let us now examine an

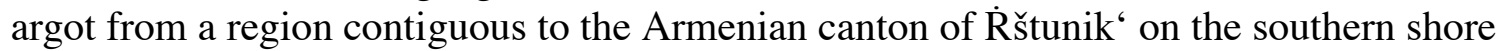
of Lake Van, that was studied by the teacher of the scholar who first brought the invented language to the attention of contemporary scholars. Karen Nikitich Yuzbashian was a pupil and biographer of the great Armenologist and Oriental scholar Iosif Abgarovich Orbeli, scion of the ancient naxarardom (the hereditary dynastic clans of ancient Armenia), who as director of the Hermitage piloted Russia's greatest museum and center of scholarship through the darkest days of the Stalin terror of the late 1930's and the terrible blockade of Leningrad by the Nazi German invaders during the Great Patriotic War (Hitler's attack reminded many Russians then of the destructive but doomed campaign of the zaznavshiisia "upstart" Napoleon chronicled above). In the postwar era, many Leningrad scholars, including Prof. Yuzbashian and his family, were housed in comfortable flats in Orbeli Street - named after the great scholar - adjacent to the pleasant wooded neighborhoods of Kolomiagi and Udel'nyi Park.

In 1911-1912 Orbeli had led an ethnographical expedition to the mountainous region of Moks (Clas. Arm. Mokk', Tk. Müküs), which is separated from Lake Van by

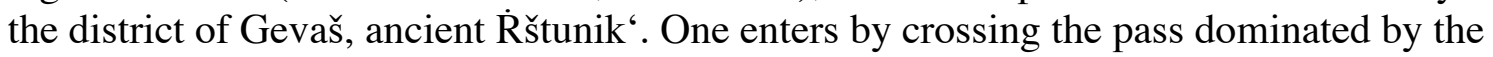
monastery of St. George called $P^{\prime} u t^{\prime}$ kavank' (lit. "Monastery of the Guest House"), whose famous rooster would warn travelers of snowstorms. ${ }^{49}$ The Armenians of Moks were bilingual in their native tongue and Kurdish; and there were also Gypsies (Roma, Arm. Lom), called by the locals mətərb, i.e., Arabic mutrib, "minstrel" (a word found in Middle Arm. also, as mtrup). ${ }^{50}$ Orbeli was impressed by the archaic character of the local culture: he notes, for instance, how the Kurdish bek would supply honored guests with pillows, one after the other, much as the Sasanian kings had done. ${ }^{51}$

\footnotetext{
${ }^{49}$ Russell 2000, pp. 121-132 n. 34; and Russell 2002.

${ }^{50}$ Russell 1987, p. 96: the poet Yovhannēs of T'lkuran asks that at his death his shroud be a green leaf (the traditional honorarium of the dervish), and that Mtrup beren inj $k$ 'ahanay "they bring a minstrel as my priest."

${ }^{51}$ Orbeli 1982, p. 34. The Babylonian Talmud records a reversal of the process: as a Rabbi lost a disputation, his rival took one mat of honor after another away from beneath him. When the last one was removed, he died: see Sperber 1982, pp. 84-95. Iranian social imagery pervades the narrative of the incident: dismissal of the unfortunate teacher, once praised as a lion, as a "fox" recalls Shapur's abuse of Vasak in P'awstos (Russell
} 2012(b)). 
In the village of Vozim (Arm. Ozm(i)) of Moks, Orbeli recorded a glossary of the professional secret argot of the men who pounded wool to make felt (called trpotkerēn, "(felt-)beaters' language"), and found that a number of lexical items were to be found in lists compiled at another village, Arnanc', from which he drew the reasonable conclusion that the jargon was widespread. Wool manufacture and the beating of wool to make felt was a major seasonal business of the Armenians of the whole region. But what is so special about felt (Arm. $t^{\prime} a t-i k$ )? Before the invention of synthetic, waterproof material, felt was the choice of need. It was warm, resistant, durable, flexible, and relatively light. Felt was essential for tents, saddle cloths, and outer ware such as the cape and tall başlık hat that still keep Anatolian shepherds warm and dry. The crowns of the ancient Armenian kings, looking rather like capsized hulls of ships, with ear flaps added, were modeled upon the ancestor of the modern başlık.

Leonardo Olschki in his brief study of Dante, The Myth of Felt, notes that in the Middle Ages felt was considered "a plebeian product and a symbol of barbarism, poverty, and contempt, if of anything." sordid, mean, and stingy; and Jews, always a marginal group, were sometimes required to wear a piece of felt on their outer clothing. The popular Old French history of the Mongols of the Cilician Armenian princely traveler Het'um, ca. 1307, describes the custom of investiture, whereby seven men raised up the new Khan on a black carpet made of felt, though they could afford much richer fabrics. In the Middle English version of the chronicle the Armenian observer exclaims, "for al the lordship or riches they have conquered, they wolde neuer chaunge theyr first gyse". ${ }^{53}$ So in the late $13^{\text {th }}$ century Armenians seem to have considered felt a lowly material. So it would appear that in Armenia, too, felt, for all its economic importance and usefulness was regarded as base and continued to be so. That would explain in part why felt-makers occupied a social niche similar to that of gypsies or thieves. We considered above the argots of subcultures outside Armenia. Subcultures are generally fairly close to the normative, dominant majority culture (with exceptions, such as that of the Roma, who are for practical purposes entirely outside it); so there is a fair amount of transfer, the slang of the standard language often originating in the argots of the underworld. ${ }^{54}$ In the case of the Armenians, who as a Christian minority in the Ottoman or Persian dominions were already a subculture in a way (their Julfa dialect, for instance, became a medium for effectively

\footnotetext{
52 Olschki 1949, p. 5.

${ }^{53}$ Burger 1988, p. 27 (Book Three, line 7 et seq.). In ancient Iran and Central Asia it would seem, then, that felt was believed to be the stuff of the clouds, whatever its earthly status, thus providing an explanation for the Mongol belief and consequent ritual. $\mathrm{T}^{\text {' }} \mathrm{ovma}$ Arcruni reports in his history of the Armenian royal Arcrunid house of Vaspurakan, $10^{\text {th }}$ century, that Šaxrik' who were hamakdēn, i.e., members of the priestly caste who knew in its entirety the $d \bar{e} n-$ the Zoroastrian scriptural revelation, law, and lore - had come to Armenia. They described their homeland as a place where tuənjean amp t'anjraxor ibrew $z t^{\prime}$ at lmeal balajew spitakap 'ayl yoyz "in the daytime the cloud was thick and dense as pounded felt, in the shape of fog glowing brilliantly white" (text in T'ovma Arcruni 1887, p. 28; Thomson 1985, pp. 90-91; and see discussion by Russell 1987(a), pp. 5-15). ${ }^{54}$ Maurer 1981, pp. 3-4.
} 
secret correspondence in the New Julfa global trade network), the felt-beaters would have been a subculture within another one. There is a large stock of Armenian loan words in Turkish, both as standard vocabulary and as slang. But the non-Muslim ethnic groups, or millets - Armenians, Greeks, and Jews - all were outside the dominant culture though not considered sociopathic as the Roma might be; so another paradigm than that evolved by Maurer and other students of argots and slangs should be constructed to describe these linguistic phenomena in what have come in recent years to be termed "Islamicate" societies.

A prosperous felt-maker of Moks before setting out on faraway business (always on foot) would host an elaborate feast for the people of the village, slaughtering several animals for the food. The occasion and its expense affirmed the social bonds that might otherwise be strained by his absence and the other tensions of life such as the constant possibility of attack. Felt-makers worked mostly in Ottoman Turkey; but some traveled on business to such far-flung destinations as Tiflis, Baku, and Rostov-on-the-Don, in the Russian Empire. Orbeli writes,

"During their peregrinations, the felt-makers worked out a rather interesting language of their own, more a thieves' argot than professional jargon. Almost every inhabitant of Moks knew a few Felt-maker words; many were even grafted onto Armenian speech and employed by people who had never plied the felt-maker's trade. But one encountered quite serious difficulties at one's very first attempt to compile a more or less thorough list of felt-maker vocabulary. Of the non-felt-makers, nobody knew even an insignificant part of the lexicon; while it was hard to get anything out of the felt-makers themselves. Nearly all were afraid to betray this 'professional secret', while those who had no need to conceal the meanings of their words and therefore had no reason to cherish the mystery, generally did not know most of the vocabulary. At the transcription of felt-maker words, there was another difficulty even more unpleasant than the responses 'I don't know any more,' 'That's what there is of the felt-maker language,' and 'That's all, there's nothing more.' In order not to be seen to refuse one's request to be taught felt-maker speech while not giving the secret away, some began to think up words. And one felt-maker, when I assured him that I would not betray the secret to their clients and patrons, answered, 'Go and give it away if you like. It makes no difference, we'll just think up a new language tomorrow' - and straightaway supplied examples of new words. Felt-makers learned their felt-maker language from their fathers. In answer to the question as to what use this language served, and to what end it was invented, some felt-makers responded that it was so that the Kurds would not understand it. Yet others averred it was a children's amusement; but the bolder ones declared, 'To make stealing easier!' It is perhaps for the latter reason that the craftiest felt-makers knew the argot best. The felt-makers were generally reckoned talented thieves, and many anecdotes recounted their artfulnessmainly it was wool they stole. It is of interest that in the 'Song at the Stone Mortar' mentioned earlier the people of Vozim are mentioned as minters of coins, that is, counterfeiters, which is an expression that generally means a skillful thief or master criminal. The "thieves"' language of the felt-makers was not something especially hard to understand, though when they were conversing among themselves rapidly it was quite impossible to comprehend it, particularly when they added the use of the "sparrows" or 
'birds"' language, that is, transposing the syllables of every word. [See infra.] In its grammar the felt-maker language conformed, naturally, to the rules of Armenian and the great majority of lexical items were Armenian as well. The felt-maker resorted to his argot only for the most important subjects of conversation. Interestingly, in every settlement the felt-makers pronounced felt-maker words precisely according to the particularities of the local Armenian dialect. Thus felt-maker speech lived the same life as Armenian; and this depended, to a great extent, on the fact that most felt-maker words were Armenian ones allegorically employed." 55

The list of felt beaters' words Orbeli compiled was published in 2002, twenty years after the posthumous publication of his ethnographical survey of Moks containing the above description, as an appendix to his glossary of the Moks dialect. The glossary of the argot is appended to this study with translation, annotation, and commentary. Several interesting points are to be noted: the bulk of the "secret" vocabulary is Armenian employed allegorically, and the phonology and grammar are entirely Armenian as well. For the purpose of additional secrecy the felt-makers spoke rapidly and employed the transposition of syllables of "sparrow" language (Arm. cti lezu), rather like the "Pig Latin" American kids used in my childhood. It is interesting, inter alia, that the Armenian-based cryptogram (referred to above in connection with the shapes of the letters of the Third Script of MS A 29) employed widely by Armenian craft guilds and other professionals was called either Atuanic" gir, "Caucasian Albanian writing" or, homonymically, aławnagir, "the writing of the dove". ${ }^{56}$ The chirping of the birds was a secret language; even as their ability to fly is a kind of locomotion enabling them to escape and hide. Some speakers, most likely to discourage Orbeli from investigating further, indeed deprecated felt-maker language as a mere children's game. The glossary was not, apparently, a closed canon: speakers could add to the argot new inventions of their own, if indeed this was not just a boast intended to unsettle the inquisitive Orbeli again.

Another Armenian secret language like that of the felt-makers of Moks was the jargon of a far lowlier guild - the traveling traders and crooks who originated in the village of Savra near Salmast in Persian Armenia, many of whom migrated to the Russian Empire in the $19^{\text {th }}$ century. They were called, derisively xač 'agot "Cross-thief", paraw nerkot "strangler of old women", $\bar{e} \check{s}$ nerkot "donkey-painter", or simply savrgetc " $i$ "villager of Savra", for they were reputed to masquerade as priests and then steal the church treasure, or befriend an old woman, then kill her, and abscond with her possessions, or just engage in shady horse-trading. The $19^{\text {th }}$-century Eastern Armenian novelist Raffi (Yakob Melik'-Yakobean), a native of Salmast and scholar and

\footnotetext{
${ }^{55}$ Orbeli 1982, pp. 8, 14, 29, 34, 39-42 (tr. from Russian mine).

${ }^{56}$ See Russell 2010 on the aławnagir; and Russell 2009 on the esoteric old Russian ballad Golubinnaia kniga ("Book of the Dove") and its Armeno-Iranian associations. The Classical Persian poet Farīd al-Dīn 'Atțār chose the metaphor of birds for his allegorical Sufi work, Mantiq al-tayr, "The Conference of the Birds". The varied twittering of the hazaran bulbul ("nightingale of thousands (of songs)") seems to form a nexus between music and language; and the bird with her wings flies between men and angels.
} 
ethnographer of his native Persarmenia, wrote in his novel Xač'agołi yišatakaranə ("The Cross-Thief's Memorial", based upon a notebook left by one Murad) that the Cross-thief "spoke with his companions in a special language that nobody can understand unless he belongs to the society of the Cross-thieves. It is a secretive, provisional (paymanakan) language; it is the argot of bandits." Though in Russia they were called Armenian Gypsies (hay c'igan, using Rus. tsigan, "Roma"), theirs was not a distinct language like Romani but "a sort of artificial, archaic, provisional language" (mi tesak šincu, hnac"ac, paymanakan lezu); and at night they could communicate employing bird and animal noises. Raffi compares the argot of the Cross-thieves to Armenian secret "bird" (cut) and "sparrow" ( $\check{n}$ čłuk) language, mentioned above. This language is discussed also by the $19^{\text {th }}$-century ethnographer who first discovered and published the Epic of Sasun, Bp. Garegin Sruanjteanc", who writes in his study Mananay ["Manna"], "Among the Armenian people there is yet another thing of value: speaking in a language derived from that of crows and sparrows, by reversal of words, as for instance saying c $a h$ instead of hac " ["bread"] or dram instead of mard ["man"], and so with every noun and verb. A similar usage obtains even in writing, where we are informed of the use of the brother of each letter: b for a, $\mathrm{g}$ for $\mathrm{b}, \mathrm{d}$ for $\mathrm{g}$, and so on. So instead of writing oski ["gold"] one writes zvel, etc." ${ }^{\prime \prime}$ (In Erevan Matenadaran MS 6731, fol. 154 v., the marginal explanation gir mi ar $(a) \breve{j}$ brne "take one letter before" accompanies the encoded $\check{c}$ “ $\breve{c} \check{c}^{\prime} c$ 'yzp, i.e., ołormea "(Lord) have mercy!") In the Armenian town of Hajin code expressions were employed: to warn a newcomer of the presence in the company of an Armenian-speaking Turk, one said $m \bar{o} \gamma \partial d z \bar{o} g \bar{e}$ (standard Arm. małə cak $\bar{e}$ ), "The sieve has a hole!" To signify he understood the warning, the Armenian guest would reply vospo $k^{\prime}$ ayod $\bar{e}$ (standard Arm. ospə k'arot $\bar{e}$ ), “The lentils have pebbles!” The people of Hajin

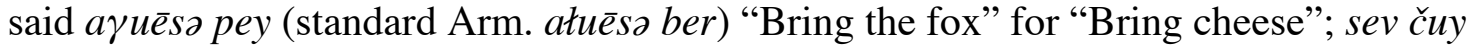
pey (standard Arm. sew jur ber) "Bring black water" for "Bring coffee"; and viyivnoc" unink" (standard Arm. verewnoc" unink") "We've somebody upstairs" for an unwelcome guest. The code words mendzə (standard Arm. mecə) "the great one" and badig osgin (standard Arm. pztik oskin) "the little gold (coin)" were England and France respectively; while the other Christian power involved in Ottoman affairs was the mendz arč (standard Arm. mec arj), "great bear", Russia. ${ }^{58}$

Felt may be a poor man's material, but in the argot of its beaters one can mine treasure. Walt Whitman, the $19^{\text {th }}$-century American bard who dreamed of a democratic polity where subculture and dominant culture were one, whose poems recognized no boundary of class or occupation or prescribed form of speech, once wrote, "Slang... is the attempt of common humanity to escape from bald literalism, and express itself illimitably, which in the highest walks produces poets and poems, and doubtless in prehistoric times gave the start to, and perfected, the whole immense temple of the old

\footnotetext{
${ }^{57}$ Raffi 1962, pp. 303-304, 309-312; Sruanjteanc'1876, p. 311 f. Prof. Bert Vaux of Cambridge University notes that the Armenians of the Van area sometimes called their Armenian speech čənčə $\gamma k n e r e \bar{e}$, "sparrows' language", presumably because of its incomprehensibility to foreigners.

${ }^{58}$ Pōłosean 1942, p. 285 f.
} 
mythologies..."59 There are aspects of the felt-makers' argot of Moks that are, indeed, strikingly poetic. As we shall see, they shed some light on the old mythologies, too. Here are some examples from Orbeli's register.

Cätkil, "to laugh", is in standard Armenian "to flower", formed clearly by extension or comparison with Armenian cicatel, "laugh", analyzing the word correctly as a reduplicative - cat-r alone is "laughter, scorn", cf. the Greek cognate gelos - and adding a diminutive suffix to produce a metaphorical homonym. The word $\boldsymbol{c} \overline{\boldsymbol{o}} \boldsymbol{v}$, meaning "large, great" in the argot, is standard Armenian for "lake, sea"; and these two easily associated images, of the flower opening in beauty and scent and the mouth opening in love and happy sound, are used assonantly in poetry: in the famous Song of the Nativity (tat cnndean) of St. Grigor Narekac'i (951-1003), who lived on the northern side of the mountains of Moks, is this well-known strophe: Ač ' $k$ ' $n$ cov $i$ cov cicałaxit cawalanayr yarawawtun erku p'aylakajew aregakan nman, "Her eyes, sea into sea dense with laughter dilated in the dawn, like two flashing-formed springs of the Sun."60 The Western Armenian poet Daniēl Varužan (1884-1915) was no less sensitive to such semantic and phonetic collocations, with their heady aroma of pagan antiquity. In the poem "Cleopatra" of his cycle Het "anos erger ("Heathen Songs", published at Constantinople in 1912), which seems to evoke the procession of the bark of Isis, we read these lines:

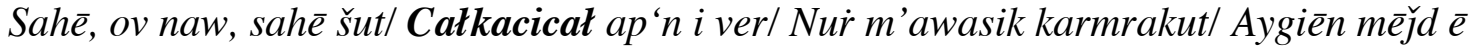
inker "Glide, $\mathrm{O}$ boat, glide swift/ Along the flower-laughing shore;/ Here a red-kerneled pomegranate/ Has fallen in you from the orchard." 61

$\boldsymbol{K} \overline{\boldsymbol{e}} \boldsymbol{c} \overline{\boldsymbol{a}} \boldsymbol{k}$, used of any kind of fire (for which Armenian possesses numerous words: hur, krak, xaroyk, hrdeh...), is literally "lightning"; cf. the t'ur kecaki, the magic Saber of Lightning of the heroes of the Sasun epic. Here it would seem a term from the higher, poetic register, perhaps from the oral epic itself, has replaced the standard word.

Xänjärör in the argot means both "wool" and "felt", but in standard Armenian the word xanjarur, "swaddling clothes", would refer particularly to the scene of the Nativity and the infant Christ. Similarly dignifying the trade is äspätäur, "bast sandal", literally "God's gift", standard Armenian astuacatur (also a common proper name as a calque on Theodōros), for the felt-makers traveled everywhere on foot. These are the kinds of selfvalidating terms any marginal group might (and does) cull from tradition for its argot.

A $\dot{\boldsymbol{r}} \boldsymbol{\prime} \boldsymbol{c}$ in the argot refers to any horned cattle, but comes from standard Armenian ariwc, "lion": for the semantic development cf. the term for fire, above. B̈̈̈̌š , the word used by the felt-beaters for the Sun, is an Armenian dialect term for an animal with a white spot on its forehead (perhaps from Tk. baş, "head") ${ }^{62}$ This may reflect an archaic concept of heaven as a living face. One type of Armenian Cross-stone ( $x a c ̌ k$ 'ar) depicts the crucified body of Christ (most do not) and is called the All-Savior (Amenap 'rkič'): a

${ }^{59}$ Adams 2009, p. 119.

${ }^{60}$ See Russell 1985, pp. 435-439.

${ }^{61}$ Varužan 1986, p. 258.

${ }^{62}$ See $H L B B$, Vol. 1, p. 164. 
Cross-stone of this type of 1279 from Urc in the Ararat region, now at Echmiadzin, shows the Sun, with a human face, resting upon the back of a bird, above the Cross and to Christ's right; the Moon, to His left, rests upon the back of a horned bull. ${ }^{63}$ According to Zoroastrian cosmological teachings, when the evil spirit Ahreman slew the beneficent first-created bull (Avestan Gav aêvō.datta-), its semen was taken to the Moon (which thus has the epithet gao.či $\theta \mathrm{ra}$ - "having the seed of the Bull") and purified; and animals and plants were born from it. ${ }^{64}$ The horns of the crescent Moon were equated with those of a bull and from the Zoroastrian practice of setting horns on the dome of a fire-temple came the Muslim custom of placing a crescent on a mosque. Since medieval times Iranians have paired the lion and Sun as their national symbol: perhaps the felt-beaters imagined the brilliant orb on the forehead of that golden beast of power and grace. Kocān means "dog", lit. "biter"; cf. the evolution of MIr. gazān "biter, stinger" into Arm. gazan "wild beast" in general. ${ }^{65}$

$\overline{A r t a ̈ r}$, "milk" is Arm. ardar, "just" in the sense of "pure". In the Epic of Kašt from the Moks region, in the Arm. dialect of Musa Dagh, and in $19^{\text {th }}$-century Western Armenian butter is called ardar iwt "pure oil". ${ }^{66}$ Oil is called paspotun or paspatäun, from standard Arm. pspłal, "to glisten". Curān, "honey”, is probably from Arm. corem, "flow". I cannot help being reminded of Mandelstam's lines of 1917 in Tristia, Zolotistogo mëda struia iz butylki tekla/ Tak tiaguche i dolgo, cho molvit' khoziaika uspela:/ Zdes', v pechal'noi Tavride, kuda nas sud'ba zanesla, my sovsem ne skuchaem$i$ cherez plecho pogliadela "The stream of golden honey from the bottle flowed/ So viscid and long, that my hostess had time to pronounce:/ Here in sad Tauris, where fortune has swept us/ We miss nothing at all - and glanced over her shoulder."

In the Song of the Birth of Vahagn, erkn-im, "being in labor", erkin, "heaven", and erkir, "earth", are used in an intricate play of dualities; and it has long been noticed that Armenian erkan "millstone", can reflect this ancient cosmological semantic cluster, with its rich array of phonetic interconnection so productive for poetry. In the argot of Moks, we find the word nerk'yäväk for "woman, wife," literally, "bottom millstone";

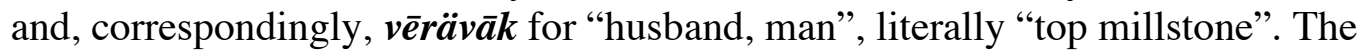
assonant collocation of the paired heaven and earth seems to be part of the fundamental linguistic furniture of an Armenian speaker; cf. the similar words for heaven and earth discussed above in Ṙuštuni.

Other designations of the two genders may reflect similarly archaic concepts and images. $\boldsymbol{K} \overline{\boldsymbol{a}} \boldsymbol{k}^{\boldsymbol{y}} \boldsymbol{y} \overline{\boldsymbol{a}} \boldsymbol{v}$, "daughter-in-law" or "young girl", is standard Armenian kak'aw "partridge", a word used commonly in folk poetry of attractive girls. In Classical Armenian texts, from the translation of the Bible onwards, the word and its various nominal and verbal derivatives is synonymous with dancing, particularly a kind of

\footnotetext{
${ }^{63}$ See Azaryan 1978, pl. 86.

${ }^{64}$ Boyce 1975, p. 139.

${ }^{65}$ See Russell 1987(b), p. 459.

${ }^{66}$ Russell 2000, pp. 90-91, n. 19; see also Riggs 1847 s.v.
} 
suggestive, strutting dance performed by women (infamously, by Herodias) ${ }^{67}$ and the complement to the felt-beaters' partridge in the argot is her c ' $i c^{6}$, "husband". This is standard Armenian c 'ic", meaning "(sharpened) stake" and "erect." In a medieval glossary it means "nail" or "tent peg"; 68 and here, it could be slang for a penis, pars pro toto of the man. (The word for "penis" itself is the equivalent of "beater", an approving nod to the felt-beater himself as well as an intuitively obvious association with the sexual act.) Movsēs Xorenac'i in his History of the Armenians recounts in chapter six of his first book how the son of Ziusudra (i.e., the Sumerian precursor of Noah), Zruan (i.e., the Zoroastrian god of infinite time), who was also Sem (that is, Biblical Shem), gave his name both to mount Sim (that is, the mountain named for Sanasar, the progenitor of the heroes of Sasun) and the province of Zaruand. And he notes, Bayc' arawel yačaxagoyn hink'n Aramazneayc ' $i$ nuags $p$ 'andran ew yergs c 'c 'oc' ew paruc' zaysosik asen yišatakaw. Ew aysok'ik zroyc 'k' sut ew kam t'é ardarew leal, mez č ‘'e inč ${ }^{\prime} p^{\prime}$ 'oyt'. Ayl vasn giteloy $k^{\prime} e z$ zamenayn, or inč' $i$ lroy ew or inč' $i$ grots', anc'anem znd bnawn $i$ girss yaysosik, zi imasc 'is zar k'ez parzmtut 'iwn imoc" xorhrdoc'. "But even more often still the ancients of the progeny of Aram in the strumming on the lyre and in the songs of $c^{\prime} c^{\prime} o c^{\prime}$ and of dances recite these in memorial. And it is of no concern to me whether these narratives are a lie or occurred in reality. But only so that you may know all, whatever one has heard and whatever comes from books, do I cover entirely in this book, so that you may understand the candor of my counsels to you." The MSS offer the variant readings $c^{\prime} u o c^{\prime}, c^{\prime} o y c^{\prime}$, and $c^{\prime} c^{\prime} o y c^{\prime}$; and R.W. Thomson compares to this passage an apparently similar usage in para. 180 of Agathangelos' History: as the lustful Trdat enters the chamber where the defenseless virgin nun Hrip'simē has been confined, the crowd inside and outside the precincts of the palace breaks into celebration. Ar hasarak ergs areal barbarec 'an kayt 'iwk' vazelovk', $c$ 'uc' barjeal mardkan "they all gave voice, breaking into song, capering and running, men raising up a c'uc'." The latter word, taken by lexicographers to mean a song or celebration, seems to be related to Armenian c 'oyc', "show" (which in turn may well be a cognate of English "show"!); and Xorenac'i's word would seem on the face of it to be a simple genitive plural of the same, meaning "of celebrations" or "displays" or the like. Khalatiants (Xalat"eanc') translates Xorenac'i's passage accordingly, песни древних арамазнийцев (армян), воспевавших на память, при представлениях и в пляске... ${ }^{69}$ rendering the mystery word $c^{\prime} c^{\prime} u c^{\prime}$, which he gives in this form, with $-u$ - rather than $-o$ - in a footnote, as "performances". But the rather wide variety of spellings in the MSS suggests, at least, that the treatment of the term as meaning a show or performance by uncertain scribes just might be a case of lectio

67 "Twist and twirl" is still Cockney rhyming slang for "girl" in London: see Maurer 1981, p. 149.

${ }^{68}$ This is the Rasūlid Hexaglot, a $14^{\text {th }}$-century compilation from Yemen. The Armenian forms, probably collected in lands under Ilkhanid rule, reflect the phonology and morphology of Cilician Armenian. In the MS, $c^{\prime}$ ic ' is the equivalent of Arabic al-watad and Persian $m \bar{\imath} x$ "nail" (cf. perhaps the present-day American expression "to nail somebody", i.e., to have sexual intercourse with them). The glossary is divided by topics; and by happy circumstance Arm. c 'ic" rubs shoulders with $t$ "atik", "felt". See Golden 2000, p. 179.

${ }^{69}$ Khalat'iants 1896, p. 44. 
facilior; so I would venture the tentative suggestion that $c^{\prime} c^{\prime} \circ c^{\prime}$ ' be the genitive plural, not of $c^{\prime}$ oyc', but of the rarer $c^{\prime} i c^{\prime}$ - the word the woolbeaters of Moks were to use pars pro toto of a man, alongside the archaic designation "partridge" of a woman. Then the patmahayr or Father of Histories of Armenia may have been referring to ithyphallic songs of men - the counterpart of the lewd kak'awk "partridge dances" of women. Such performances are well attested in Armenian antiquity. A sermon attributed to the fifthcentury Catholicos Yovhannēs Mandakuni (more likely to be the work of another Catholicos John, Mayragomec' $i$, who lived three centuries later), has become the locus classicus for discussion of Armenian gusans, or minstrels. In "Concerning the lawless theaters of the demonic", the incensed cleric declares weak-willed women particularly susceptible to the lewd suggestions of drama: "For the custom itself is evil and so are those who encourage it: wine (gini), the minstrel (gusan), and Satan," where "women are cast into the role of prostitutes; and men, as rutting stallions mounting mares (jioc " matakaxazac")." There are also clowns or jesters at these performances: "For where jesters $\left(k_{\left.a t a k k^{\prime}\right)}\right.$ and minstrels and lewd play (xat) and mockery (catr) be; there the demons, too, join in the dance., ${ }^{, 70}$ One recalls the ithyphallic satyrs who lurk at the beginnings of satire itself.

The slang of the felt-makers of Moks may perhaps then have preserved an archaic and antic designation of men and women. The felt-beaters used the verb xirkil or xilkil, for the sexual act, lit. "plow a winter field") - cf. the English idiom "plow" for "fuck"; the totičc lit. "beater" (vb. tatil), as noted above, is the penis. ${ }^{71}$ Xärnäkum was the party, mentioned earlier, that a felt-maker held before going away. Its literal meaning, "confusion", possibly has lewd sexual overtones beyond a social mixer: xarnel just means "mix", but Arm. xarnakumn is often in Classical and homiletic literature used to imply illicit intercourse. The party might have been more than a mixer.

Kyətalämān is the mouth, lit. "spoon holder", but whatever salacious metaphors, wild parties, and the like the felt-makers enjoyed, the širip' $x \bar{a} t$ was still the woman of the house, lit., the one who moves or plays (xałam) the ladle ( serep $^{\prime}$ ). In the traditional Armenian glxatun - a house with central hearth beneath the squinch-constructed smokehole (ert ${ }^{i} i k$ ) - the ladle hung from the chief of the four pillars supporting the dome, and the woman who held the ladle fed the family. ${ }^{72}$ Some things never change, and God be praised.

\section{APPENDICES}

\footnotetext{
${ }^{70}$ Mandakuni 1860, pp. 131-137.

${ }^{71}$ The Middle Iranian loan framaštak is a Talmudic Aramaic hapax meaning "penis" that one quickly recognized in the common Modern Arm. hrmštk-el, "shove, push in"clearly old, but not attested in the classical texts, at the time of whose composition *hramaštak would presumably still have carried its slangy, lewd overtones (see Russell 2013(a)).

${ }^{72}$ See Abrahamian and Sweezy 2001, p. 108.
} 
1. Description of St. Petersburg Institut Vostokovedeniia ("Institute of Oriental Studies", abbrev. Or. Inst. here) MS A-29.

Yuzbashian 2005, pp. 76-77.

“142. IV, A 29, Miscellany. Lacks general title, contains diverse materials: examples of cryptography, prayers, theological compositions, dictionary of a hypothetical language, predictions, medical advice, etc. The manuscript was intended for personal use and has the character of a draft. Occasional jottings are left out of the description.

I. Fol. 1a. Cryptographic alphabet corresponding to Armenian from $a$ to $k^{\prime}$, followed by [the ligature] ew, $\bar{o}, f$; abbreviations ac im [i.e., Astuac im, "My God"] and an example of cryptography.

II. Fol. 2a. Multiplication table, Arabic numerals.

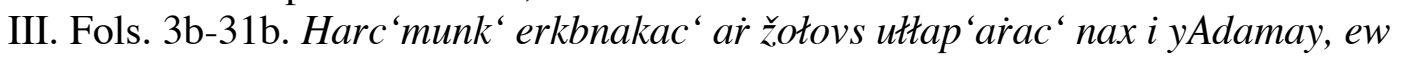
patasxanik' noc 'in anddimut'eanc' ["Questions of dyophysites to the councils of the Orthodox, beginning with Adam, and the responses to the refutations of the same"](fol. 5a), named in the preface as Catik c'ankali ["Desirable flower"] (fol. 3b), beginning: Harc': Orpēs stetceac"Tēr Astuac Adam... ["Question: When the Lord God created Adam..."]. Refutation of the errors of the dyophysites in the form of questions and answers. The authors of the composition are Yakob and Grigor (fol. 21a-b, acrostic; fol. 23a, attribution). References to the works of Grigor Tat'ewac'i, Pseudo-Dionysius the Areopagite, Cyril of Alexandria, etc.

IV. Fols. 3a-34a. Bank' omank'xrt'ink' ["Some difficult words”], beginning:

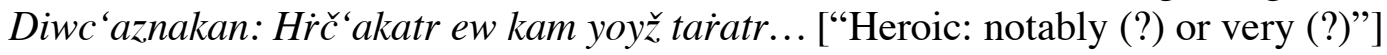
Explanation of particular "difficult" words.

V. Fols. 37a-44a. Aylakan lezu or ew asi ruštuni ["Allegorical language which is also

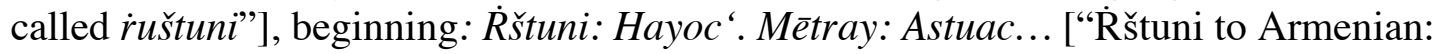
Mètray=God"]. Alphabet and dictionary of the hypothetical Rंuštuni language. Text published in Aganian [Ałaneanc'] 1894, cols. 845-852.

VI. Fols. 44b-49a. Cryptographic alphabet and texts of medical and other content. The same script is found on fols. 2b, 63b-64a, and 67a, and on the [inside] cover. See Abramian [Abrahamyan] 1973, pp. 244-280 with illustration.

VII. Fols. 50a-62b. Predictions, medical advice, the beginning of an explanatory dictionary, explanations of some philosophical terms, etc.

VIII. Fols. 64b-65a. Aybubenk' bolor groc" Hayoc 'ew rusac ' ["Alphabetical list of all the letters of Armenian and Russian"], beginning: $a$-Aa. Comparative table of the Russian and Armenian alphabets, with the names of the Russian letters: az, bugi, veti [i.e., Az, Buki, Vedi], etc.

The manuscript is a convolute of two parts, on white paper (fols. 1-36) and blue. The copyists of the first part are Yakob and Grigor (?). Paper with Georgian text is glued into the binding; and several other signs indicate the provenance of the manuscript from the milieu of Armenians in Georgia. From the collection of Fr. Aganian [Ałaneanc']. On fol. $3 \mathrm{~b}$ is the seal of Grigor (the copyist?) from 1792; the manuscript was copied around this date.

$17.3 \mathrm{~cm}$. x $10.5 \mathrm{~cm}$; 67 fols.; text in a single column; 21 lines [per page]; paper; šłagir [Armenian cursive]; cardboard covers; inner front leaf preserved." 
The MS contains also, on fol. 21r, a short list of the abbreviated signs and hieroglyphs one finds in other Arm. MSS. ${ }^{73}$ There is a text on the dimension of Noah's ark (fol. 8v.); notes on the Antichrist (Arm. nern) and his descent from the tribe of Dan (fols. 14v., $25 \mathrm{v}$.), and instructions for the recitation of Psalms so that one may behold divine light (ard et 'e kamis gitel k(a)m tesanel zloys gerazanc' $i k$, "now if you wish to know or see the surpassing light...)(fol. 34v.). ${ }^{74}$

2. Glossary of the Rंuštuni language, MS A 29, published by Ałaneanc' 1894 , cols. 845852. I have checked the reading by Fr. Ałaneanc' against my own direct transcription of the manuscript, and generally have accepted his reading. Where he has replaced a word thought obscene by a euphemistic circumlocution I provide the original. The MS gives the R̈uštuni in the first column; the Armenian translation by the author of the MS, in the second; in the third, I add the English equivalents, though sometimes the Armenian itself is unclear.

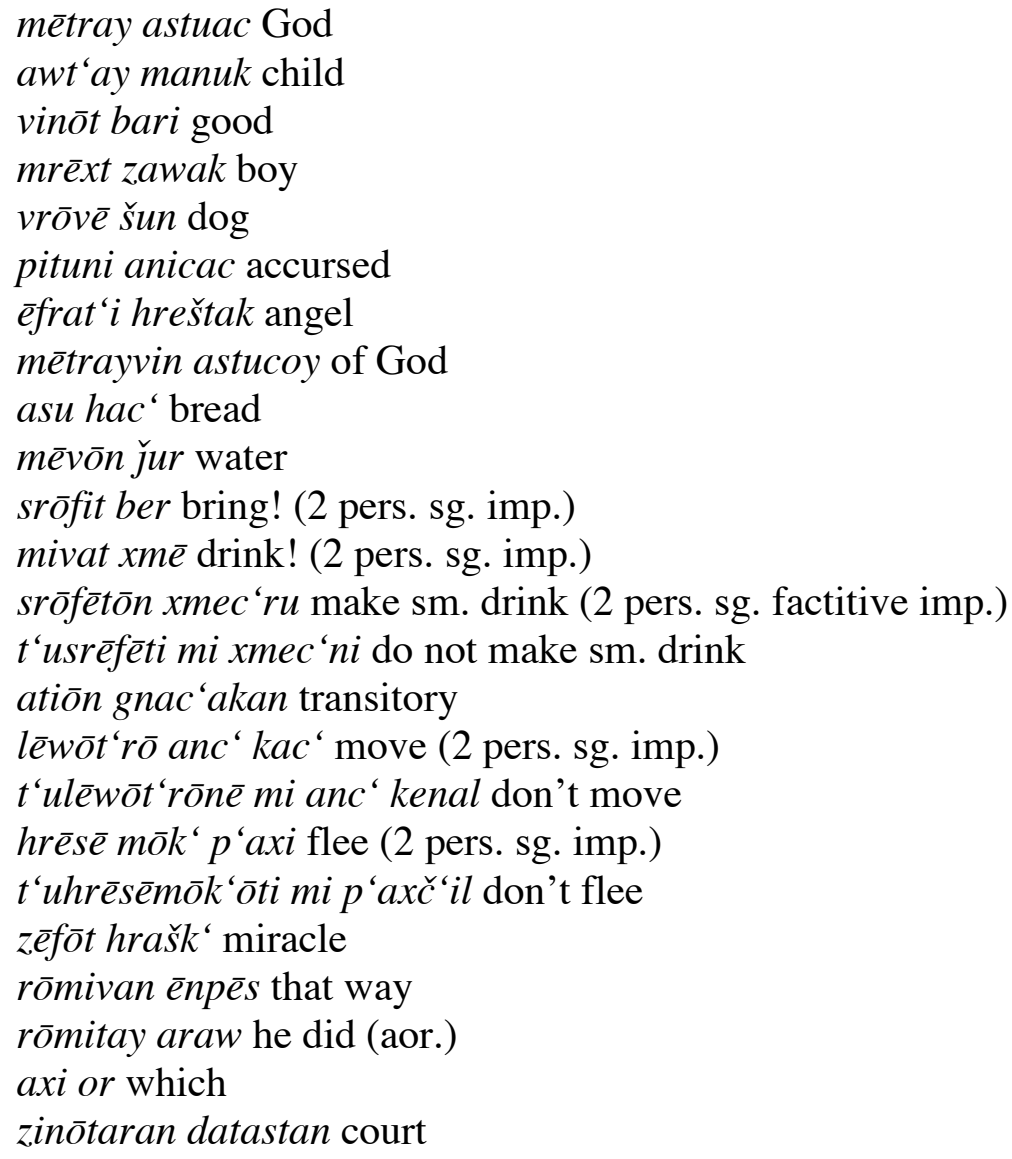

\footnotetext{
${ }^{73}$ For a discussion of these see Russell [2013].

${ }^{74}$ This recalls the instructions given by St. Gregory of Narek, $10^{\text {th }}$ cent., for priests preparing to offer the Divine Liturgy to recite certain passages of the $33^{\text {rd }}$ chapter of his 95-chapter cycle of mystical and theological odes, the Matean ołbergut'ean ("Book of Lamentation") until they behold a visible light coming from heaven: see Russell 19961997.
} 
rōmit aray I did (aor.)

liwōtinē t'agawor king

p'ifōn išxan prince

xway krak fire

at'rōn k'uray crucible

ap'ōn zndan prison

xut'ar č'ak'uǰ hammer (loan from Tk.)

grōmē mašay I was worn out (?)

alōt arcat' silver

offeh oski [sic!] gold

zrut' xunk incense

šōnē č ešmak eyeglasses

$k$ 'at'or bun nest

bihōlon yałt'ot victorious

č'aruk'ōn mzrax spear

sōnēr lusin moon

ziwōtēp aregakn sun

šuray astet [sic!] star

hatp 'ay mukn mouse

haxinōn banōt [sic!] workman (pres. part. act.)

hoxgayhoxinōn jukn banōt fisherman (?)

awridlōbi džoxayin hellish

awrid džoxk [sic!] hell

silubēn satanay Satan

lōłōp 'i sadayēl Sadael

lōgōfin beliar Belial

nimō arew sun

nimōfrē dusēkaw [sic! standard Arm. durs ekaw] he came out (aor.)

nim dus [sic! standard Arm. durs] outside

rōm ari come! (2 pers. sg. imp.)

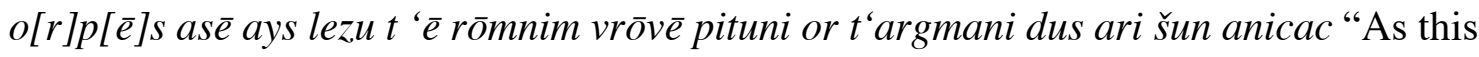
language says, Rōmnim vrōve pituni, which is translated, 'Come out, accursed dog!'" [This abusive challenge in $\dot{R} u s ̌ t u n i$ is then written out in the second cipher, of fol. 37a, with a symbol for Arm. $v$ differing very slightly from the one in the key.]

veriōtim manazil [Arabic manāzil, "houses", used as an astrological term in Arm.] axin jew type, form

axvay hanon (?) - possibly Arm. hanel "remove"?

hōmēn hayi he looks

suti biz bristle

taw è lin ôrhneal $\bar{e}$ he is blessed

afit'ōnē k'ristos Christ

löbi a[stuaca]yin(?) divine; Ałayeanc' reads this as the arm. adjectival ending -ayin.

sisō glux head

sisōvēn šlink' bowing, humbling of the neck and head 
ašwu jern hand

asēnē hambarē [sic!] be patient! (2 pers. sg. imp.)

asēn hambark' [abbrev. of hambarec' 'ék'?] (2 pers. pl. imp.)

sfōnèt disnim [sic! standard Arm. tesnem] let me see (1 pers. sg. pres. subj.)

asēnēsfōnēt hamb[e]rē tesn[e]m hambar[ec'‘̄e]k' noc 'in kerpi “Asēnēsfōnēt: 'Hold on, let me see!' [The plural] 'Hold on' [is said] the same way."

[A list follows of the $\dot{R} u s ̌ t u n i$ numbers one to ten:]

šuš, fēeno, krōn, tēe, Łōvēn, asur, krōmēn, hō, zunē, tōff.

[A list of $\dot{R} u s ̌ t u n i$ words with the Arm. letters $i, l, x, c, k, h, j, t, \check{c}$ with patiw superscript, i.e., the numbers 20-100, above each in order:]

finōs, ibōr, sōlir, drōmēe, xōf, slōnē, ōmēe čèmsay, mēvalèt.

very̌ hambaris $x \bar{o} g \bar{e} n \dot{r}$ "That is all of these numbers; $x \bar{o} g \bar{e} n$ [is] 1000."

[Below this is an elaborate church-like drawing inscribed with the name Grigor, doubtless one of the pair named in the acrostic poem. Then the list resumes on fol. 40b:]

sōlēfan amenayn all

tołaš tačar temple

siforot'èm bnu[t'i[wn] nature

arafēl arak'eal apostle

hramēt'èm hretēn fiery

trōpēn mard man

trōpenni mardoy of a man

aspari šrlataser $(?)^{75}$

šuršêtōm ant'aram imperishable

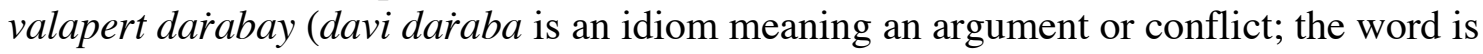
Arabic in origin and means literally "beating").

asp šrlat (?)

axbrōsi hetak'rk'ir interesting

xwēm golov being

prēer azg clan, nation

prèrèm azgēn from the clan, nation (abl. sg.)

aswōt ark'ay king

aswōtin ark'ayin of the king (gen. sg.)

aswōtr ark'ayic' of the kings (gen. pl.)

\footnotetext{
${ }^{75}$ If one reads talatasēer, then "lover of vice" (Arabic ghalat, "transgression" + -sēr "loving, -phile", used in various compounds and a verb in Arm., see Russell 1987, p. 44.); and cf. asp šrlat (Ałaneanc') or łalat (my reading) below.
} 
aswōt trupē ark'ayakan kingly

aswōtoruhip ark'ayuhi queen

aswōtutin ark'ayacinn the king's progeny

atr got thief

šinoxxa gerezmand thy grave

adron mizan scale

abid kšerk' 'weights

ōtēr mulk' king (Arabic)

bēšōy šinē make (2 pers. sg. imp.)

bēšôlêf šinec ' $i$ I made (aor.)

bēšólēt' šinec 'ir you (2 pers. sg.) made

sirafēt adap' xanay school (Persian, adab xāna)

č $u$ šet msxal a measure of weight (Arabic, mithqāl)

mêt dang a piece, measure (Persian)

sēm kēs half

xalēš anem I do

t'ap 'êt'an t'anakaman inkwell

ap 'it'rōnap 'it' hangstaran place of rest

ap 'it'rōnap 'it'inō hangstaranumn in the place of rest (loc. sg.)

apaxrōn č'ar evil

t'alim ptut fruit

zat' cnund birth

srōfat'ēm k'unem I fuck (Ałaneanc': serakan yaraberut'iwn "sexual relations")

sibem $k$ 'nem I sleep

sibēnōt' $k$ 'nenk' we sleep

bzēm $k^{\prime}$ oy $[$ sic $]$ your

asatrōn mayr mother

asatrōnib mayr im my mother

tētway t'uz fig

sēmat' xnjor apple

sēmsay tanj pear

agbude xałoł grape

mizway hon there

drōbenit'ay mardkayin human

abzēdon k'amar girdle

t'ulabi t'ołay [sic] I was left

sisbēlib sart'ap' weaponry (Persian)

apazinam bōrak $[\mathrm{sic}]$ borax

sum but'ak tuner (knob used to tighten the string of a musical instrument)

zit' $\bar{o}$ ē $b$ čagar $[$ sic] bunny rabbit

buxut'i xoz pig

$k^{\prime}$ emasi $k^{\prime} a w t^{\prime} a \dot{r}$ hyena: the Arm. word is used idiomatically in the dialect of Tiflis to mean also an old witch; see Martirosyan 2010, pp. 791-792.

bizmot" puc' cunt (word puc' almost erased, and note added: $k(a) n(a) c$ ' $i$ amot ' $n \bar{e}$ noyn ad mardkayin orovayn noyn ccuk "it is the feminine shame[ful part]; 'thy $\mathrm{X}$ ' is the same thing; human belly; nipple for sucking, the same"). 
bizmot'n puc'd thy cunt; Ałaneanc" renders as yetoyk" "buttocks".

gxōvēt'n ord thine arse

gxōvēt'n or arse

$\bar{e} t$ 'bay cock, penis; Ałaneanc" renders as cacuk andam "hidden membrum".

zint'afi p'anjaray window (Persian)

asbett ' $k$ 'un d" $y$ sleep $d " y(?)$

nêwran t'awilay barn, stable

abzēn daxtak [sic] board, plank

$\dot{r} \bar{o} s b \bar{e}$ krapašt idolater (cf. Persian rōspī "whore"?).

$n \bar{e} w t^{\prime} \bar{o}$ darak' [sic] shelf

jinat' tut' $i$ box (Tk.)

dèmt'are catik flower

dēmt'awlō całkeal flowering (ppart.)

čarōd kōxbēk [sic] button

sēlin sōtōmōn [sic] Solomon (cf. Ar. \& Tk. Selīm).

$p^{\prime} \bar{e} t^{\prime}$ awnit' $p$ 'ilisōp'ay philosopher

$p^{\prime} \bar{e} t$ 'fanêt'ōn p'ilisop'ayu[t']i[wn] philosophy

$\bar{e} u$ aysu by means of this (inst. sg.)

peyguō payman condition

pēygvōye paymanaw by (means of the) condition (inst. sg.)

$\dot{r} \bar{o} l v \bar{e}$ ašxarh world

rōšmēxe erkir earth

$\dot{r} \bar{c} c ̌ k i$ erkink' heaven

rōstēk' hurak' heat (?)

ṙ̄osōmêf mašà small saw (?)

tiyubiwt' pattasar Balthasar

frōt 'am cōvi ali wave of the sea

filsup'ē naw ship

fičatōn geami boat

fit've kot $^{\prime}$ handle

čêm karmir red

olt' kananč' green

sibjēe sew black

èbōn mavi blue

$k^{\prime}$ 'attōn cirani purple

$k^{\prime}$ ébut' moxir ash

$k^{\prime}$ 'insōle at'ar attar

tigtō stwil to be shortened

tislōt lēvieat'"n (? possibly lawut'iwn "goodness").

tip 'anōs verew above

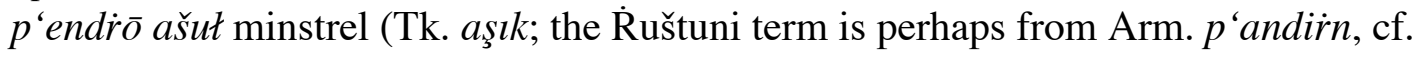

Ossetic faendyr, the lyre played by the ancient gusan- $k$ " "minstrels").

šêsvōk $k^{\prime} \breve{s} e y d i l i$ (possibly the Ar. formula of an oath, šahìd Allāh "God be my witness!" cf.

Russell 1987, p. 115 line 116 and n.).

zit'rōt' mōvi fine silk cloth (?)

abde karas jar 
sadēb hor hole

séfbētuyi serōbe $\bar{e}[$ sic $]$ seraph

asbil atik' innards

$s t^{\prime} \nmid \bar{o} v$ ałung [sic] fingernail

dērō kext donkey's packsaddle (for kex?)

miv otn foot

$\bar{o} l \bar{o} t^{\prime}$ olok'shin bone

c'up'ēt' cunkn knee

nivlō tur give (2 pers. sg. imp.)

be txxo xp' $\bar{e}$ strike (2 pers. sg. imp.)

bettxōt' $\bar{e} x p$ ' $\bar{e} c$ ' $\bar{e} k$ ' strike (2 pers. pl. imp.)

t'ubetxōt' $\bar{e}$ mi xp 'ée' do not strike (pl.)

eyvoyi ver kac'stand up (2 pers. sg. imp.)

t'uêyvoyi mi ver kenal do not stand up

$d v \bar{o}$ dur ayn orcakenir come and vomit it up (<orckal?)

dōlōt' dexca [sic] peach

sišo šlor [sic] plum

pravt plor sabin $^{76}$

pitur mori blackberry

dēmdō mirk' [sic] fruit

cundō jor valley

$s \bar{o} t^{\prime}$ sar mountain

bēlfay oč 'xar sheep

otrō uxt promise, covenant

ǰêtēebèd sxalmunk' error

šèmt'ōbrōvēn hastatut 'iwn establishment

beysay zstambay rebellious, belligerent

tōčēnt' $\bar{e}$ b basmay dried dung used as fuel

žařu łarłlu drowning (?) (<Ar. yarq- + Tk. -li)

žant'êp' łamiš grass (Tk.)

t'utēb alt'ap 'ay cf. att' $p$ 'el, to wash laundered clothes halfway

lōgdè lagan bowl

muhrēwē muhaǰà refugee, migrant (for Ar. muhajir)

sstēmp' momapat wick

astēp 'ót' varaz wild boar

yēbōxtrōn nałaray drum

mišwōt' $\bar{e} b i$ č 'ibux pipe (Tk.)

xunt'avē sarut mollah's turban

zēmbi xlink' Arm. dialect, šlink' "neck".

zèmbadi t'uk' sputum, spit

$z \bar{e} m b \bar{o} v r \bar{e}$ ayn $\bar{e}$ orum asen gorcarar or $\bar{e}$ sar "that is the one they call the agent, who is chief" (Ałayeanc" reads the last word as ur "where").

tamč 'éle $\bar{e}$ or $\bar{e}$ kariǰ [sic] "which is scorpion"

${ }^{76}$ See Bedevian 1936, p. 342 no. 1981; and $H L B B$ s.v. 
p 'ēlezzmay or ew asi morm or yoyž xacatē "which is also called morm, which is very prickly"

žanlibōn or ew asin ozni "which they also call a hedgehog"

On fol. 44b are three more words, following the key to the third script:

Ayl ews bark" ("Some more words"):

miłduvēwk' tramabanu[t']i[wn] logic

selduvēwk' čartasanu[t']i[wn] rhetoric

ǰèmsayvēwk'k'erakanu[t']i[wn] grammar

3. Glossary of the secret language of the felt-makers of Moks, Orbeli 2002, pp. 355-358: Argo sherstobitov ["argot of the wool-beaters"]. Orbeli's use of umlaut and circular superscription (here replaced by a macron) denote short and long a; other umlauted vowels are as in Turkish. The $-y$ following a consonant denotes palatalization. His comments are in parentheses; mine, in square brackets.

Ämärnač'or, stone.

$\bar{A}$ njez, mullah (primary meaning [=p.m.], "raven").

$\bar{A}$ tip// äntəēp, bad, ugly.

$\bar{A} \dot{r} O c^{\prime}$, oven.

$\bar{A} \dot{r} u c$, horned cattle [from Arm. ariwc, "lion"].

Aspätäur, bast sandal (p.m., "God's gift").

$\bar{A} v g y \bar{e} r$, beard.

Artär, milk [from Arm. ardar, "just" in the sense of "pure", cf. ardar iwt, "pure oill", for "butter"].

Bä̌̌o, sun.

Baläzök, forearm (p.m., "bracelet").

Bə்̀ān, small cattle (p.m., "bleating”) [more likely from Kurdish beran, "ram”].

Gyärdän, necklace (p.m., "neck”).

Gyōsil, to beat.

Dös, breast [from Tk.].

Zarō, lira coin (cf. Käžö) [possibly from Iranian zarr, "gold"; Ottoman Turkish oski, "gold coin" is a loan from Arm. oski, "gold", the latter in post-Classical dialects generally pronounced with on-glide $v$-].

Zināc, meat (p.m., "slaughtered").

T'evnuc', clothing (p.m., "shoulder cloak").

Ink'y, good, beautiful.

Löträ, see Āspätäur.

Xänjärör, 1. wool, 2. felt [from Arm. xanjarur, "swaddling clothes"].

Xärnäkum, party held by a felt-maker before going away (p.m., "confusion”) [possibly has lewd sexual overtones; Arm. xarnakumn "mixing up" is often in Classical and homiletic literature used to mean "illicit intercourse"].

Xätxätun, raisin (p.m., something piece by piece, or with pits).

Xirkil// xilkil, perform the sexual act (p.m., "plowing a winter field") [cf. the English idiom "plow" for "fuck"]. 
$X u z$, Turk [possibly from Ghuzz or Oghuz, Turkic tribal names, with popular etymological and pejorative contamination by Arm. xoz, "pig"].

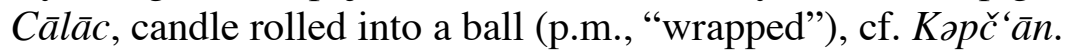

Cäłkil, to laugh (p.m., "to flower").

Cävār ānil, to talk too much (p.m., "to cook pilaf").

Cernuc", stick for beating wool [into felt] (p.m., "handle").

$C \bar{e} t$ 'il, to eat (p.m., "become smaller") [cf. the Arm. idiomatic jet pet "small and great"].

Cêt' $u n / / c \bar{e} t^{\prime} \bar{a} u n$, dinner.

$C \bar{e} k \bar{a} c$ ', trousers [perhaps from Arm. cak, "hole", into which the leg is inserted, cf.

Biblical Hebrew mixnasāȳim, "idem", lit. "twin inserters"].

Caxk'yěš, pipe for smoking (p.m., "chimney"), i.e. cux k'ašs "smoke-puller".

Cavil, to drink.

Cux// cāux, tobacco (p.m., "smoke"), perhaps shortened cxaxot, lit. "smoke-grass".

Curān, honey [probably from Arm. corem, "flow"].

Curil, to run away [cf. Curān].

$C \bar{v}$, great (p.m., "sea").

Käžö, lira coin, cf. Zərō [possibly from Arm. k'a(r)žēe "it's worth"?].

Kākut// kākāut, cotton wool (p.m., "soft").

Känäč ‘ämusk// känä̋̌c ‘ämäusk, Russian (lit., "green-eyed”).

Känt", woman, wife (p.m., "handle of a vessel").

Kānč ‘̄an, rifle (p.m., "shouter").

Kāvkut, shoes.

Kārmir čür, wine (p.m., "red water").

Kÿ̈р', bread.

$K \bar{a} k^{\prime} y \bar{a} v$, daughter-in-law, young girl (p.m., "partridge").

$K \bar{e} c \bar{a} k$, fire (p.m., "lightning").

Kyəlxänис', hat (p.m., "headgear")[standard Arm. glxanoc '].

Kacān, dog (p.m., "biter").

Kacēyk// kacēe, daughter, girl (p.m., "skein").

Kәрс̌ ‘ān, candle (p.m., "kindling"), cf. Cālāc.

Karvān, nut.

Kyatzlämān, mouth (p.m., "spoon holder").

Kträcurēk [-urēyk], a five-piastre coin [contains standard Arm. ppart. ktrac, "cut off", so "piece"].

Katril, steal (p.m., "cut").

Katruc', 1. knife, 2. saw (p.m., "cutter").

Korəngyil, go away, escape (verb formed from p.m., "heel").

Kyörcāc, satin (lit., "woven").

Kork 'yêt', felt-maker's tool (lit., "stick with a curved end").

Korangyän c'ānil, see C'ānil.

Korkil, to arrive.

Kuru, bag for wool (from the imperative form of the verb "to lose" with the sense of "hide!").

Härt"nuc', bag, wallet (p.m., samannik "mud brick" (?)).

$\check{C} \ddot{a} t \bar{a} c$ ", mouth (p.m., "watermill").

Čärtzk'yar, root tooth (p.m., "white stone"). 
Čəmäc'əc'il, to kill (p.m., "squash, squeeze").

Čmil, aorist $\check{C}$ วmav, to die (p.m., "to be squeezed").

Mäzwor// mäzwür, 1. goat, 2. priest (p.m., "hairy”).

Māuň̌, 1. blanket, 2. felt.

Māusk, eye (cf. also Musk). Muskäyn, early in the morning, at dawn, tomorrow. ${ }^{77}$

Māuskil, to look.

Māt, brother (p.m., "finger").

Mērāc, yoghurt (p.m., "fermented").

Munč', 1. socks, 2. shoes.

Musēk, night.

Musk, window. Cf. Māusk.

Nerk'yäväk, woman, wife (p.m., "bottom millstone").

Nostvāc, floor [lit., that which is sat upon].

Nofil, to sleep.

Šenk', 1. house, 2. door. [Cf. standard Arm. šênk', "building".]

Šarēšt cāxil, to collect alms.

Sirip' $x \bar{a} t$, woman of the house [lit., the one who moves or plays-Arm. xałam - the ladle-Arm. šerep'].

Šórāc, milk (cf. Artär) [cf. šór, "stream of milk from a cow's udder" in standard Moks dialect, Orbeli 2002, p. 304].

Šórzkot, man of the house.

$\check{C}^{\prime}$ āla' $n k^{\prime} y$, Let's go! [Cf. Indic čal- through Romani?]

Č'ärč ‘ärac, $t$ 'an [i.e., yoghurt mixed with water] (p.m., "tortured”).

Č'ur, money (p.m., "dry”).

Č $\bar{o} n \ddot{a}, \mathrm{Go}$ ! [From Kd. ̌̌u- "go"?]

Pätärčil, to kiss.

Pärc', hand.

Pästil, to defecate.

Päräkäpuč, horse [lit., "fine-tail”].

Päräkil, to urinate.

Pärkupučäx, paper [lit., "fine edge, corner (?)” Tk. bucak].

Pat cak əe, Careful! They're listening in on us! This will give us away! (p.m., "there's a hole in the wall.")

Partun// partan, felt (cf. Xänjärör).

Paspałun// paspałäun, oil [from standard Arm. pspłal, “to glisten”].

Pülür, piaster.

Pün, house (cf. Šenk") [from standard Arm. bun, "native", derivative verb bn-ak-em, "dwell"].

Sēzāe, wife (cf. Kānt', Nerk'yäväk).

S̄ēzuc", see $S \bar{e} z \partial \bar{e}$.

Sêx, dagger (p.m., "riveting hammer").

Suril, 1. to run away, 2. to escape (cf. Curil).

Väzān, dog [possibly from Arm. vazel, "to run"> "runner", cf. Kəcān].

${ }^{77}$ HLBB, Vol. 4, p. 95, cites mauskil "to look" and musk "eye" as cackabanut 'yun "secret language"; and mentions also musēk "night". 
Väzkān, lentil.

Vänk'yəēe, 1. a little, 2. There isn't any!

Vänk'yil, to steal, cf. Katril.

Vänk'yōm, theft.

Värak, daughter-in-law, young girl (p.m., "chick”, cf. Kāak'yāv).

Västkot, father.

Väräc'c 'il, to steal, imperative Väräc 'c 'u' (cf. Vänk'yil).

Väril, to go, aorist väric'. See also Vaērnäl.

Vērävāk, husband, man (p.m., "top millstone").

[Vəērnäl], to go, aorist vəērc" äv.

Vilkil, see Suril.

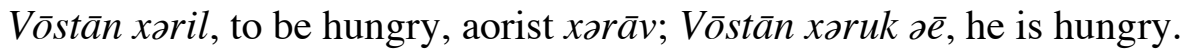

Vōstänc's, wheat.

Tāxtāk, tongue (p.m., "board"); see also Taxtəxkičc.

Täknuc", felt (p.m., "bedding"), cf. Pərtun.

Täkpün, mosque. (From Ar. takbīr, the act of declaring Allāh hū akbar "God is great"?)

Täř̌ür, vodka (p.m., "bitter water").

Tätäkān, bull; see also Tätōt.

Tätôt, see Tätäkān.

$T \bar{a} k^{\prime} y c ̌ u ̈ r$, tea (p.m., "hot water").

Tełāc, see $K^{\prime} y \ddot{a} r a ̈ n \bar{a} c$.

Taxtaxkič‘, see Tāxtāk.

Tәр' 'ssil, to carry off.

Tәр 'ič', penis [lit. "beater”, cf. standard Moks dialect təp 'il, "to beat”, Orbeli 2002, p. 336].

Taxôt (1), 1. felt-maker, 2. man of the house.

Taxōt (2), ram.

Tip// top, good, beautiful (cf. Āntip).

Tir-päc", door (p.m., "Open! Shut!”).

$C$ 'a $x$, beard (p.m., "straw").

$C^{\prime}$ 'anil, to fear.

$C$ 'aruk, boy, son [cf. standard Arm. c'ruk, "snout"].

$C^{\prime} i c$ ", husband; cf. Vērävāk. [Cf. standard Arm. c'ic', "stake, erect".]

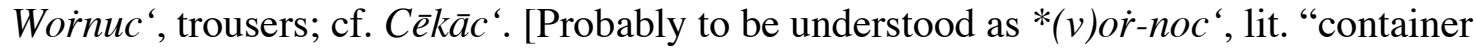
of the anus".]

Worvänk'y, cacık [Tk., thickened yogurt to which diced cucumber or yogurt is added] (p.m., "sediment, waste").

Wotnuc", 1. socks, 2. shoes. [Arm. *(v)ot-noc", lit., "container of the foot"; cf.

reconstruction of wornuc", supra.]

$P^{\prime} \ddot{a} t$ ‘ $\partial t^{‘} \ddot{a} c$, cigarette [lit. "roll up”].

$P$ 'êtatil, to fuck. [Possibly from standard Arm. p'ettel, "to pluck out".]

$P$ 'it'nil, to be tired.

$P^{\prime} u k \bar{a} r / / p^{\prime} \bar{a} u k \bar{a} \dot{r}$, daughter-in-law, married daughter.

$K^{\prime} y \ddot{a} l a ̈ k$, upper part of the torso (p.m., "boat on inflated skins")

$K^{\prime}$ yämuc', loop on a stick.

$K^{`} y \bar{a} r$, village. (From Semitic qīrya?) 
$K^{\prime}$ yäränāc, cheese; see also Tetāc.

$K^{\prime}$ yet' $r i k$, bag for wool; cf. Kuru.

$K^{\prime}$ yer $\dot{ } a ̈ s ̌ t$, wrist (p.m., vila (?)).

$K^{‘}$ yəšŏt, 1. village elder, 2. shepherd (p.m., "herder").

$K^{\prime} y \bar{o} \breve{s}$, bek [Tk. or Kd. chieftain].

4. Texts in the "third script" of Petersburg MS A 29.

Although the author of the MS seems to have intended his script for use with his invented language, and for philosophical tracts, it is employed here mainly to encode all or part of various magic spells. A number are transcribed and translated here: where they mix the standard Mesropian script of Armenian with the cipher, the words in standard Armenian are transcribed in bold face. Sometimes but not always they are the most innocuous parts of the text, unsurprisingly; but sometimes also a word may be written with a mixture of the two scripts, either with the intention of complication for reading or perhaps because of a lapsus calami. In at least one case the scribe confuses the characters for the letters $g$ and $d$, which are adjacent in the Armenian alphabet - an indication that although he wrote the cipher elegantly, he was not so thoroughly practiced in it as not to be thinking any longer of which letters of the standard alphabet its characters replaced. One interesting lexical feature of the spells is immediately evident: over and over, the scribe idiosyncratically employs (and variously spells) the adverb anpatčar , literally "causeless" and generally used as such in Clas. Arm., with the secondary meaning, now most common in vernacular Mod. Arm., "definitely, absolutely". This may reflect the idiom of the day: on 12 March 1747, for instance, an Armenian merchant of Tokat employed the word to mean "must absolutely" in addressing a letter to a merchant from Bursa at Canton in China. ${ }^{78}$ It is at any rate an indication that, whatever his source for these incantations, the rendering of them is his own.

Fol. 45v. grē t'e filani ordi filann korč ' $i$ (magic square) ays veroy greal tlisms eōt'n ktor t'tt'i vrēn ōrēnn [for ōrinak?] mēk ktorn tar kraki vrēen dèr gc'ac' c'a'aes [for gc'ac č'es?] asa: lic' zeresn anarganōk'. Filan ordi filanin hōr anun tu [for tur?] ew apa asa ayn satmosn. A(stua)c o nmani k'ez? minč 'ew ayn tetn or asē o(r)p(ēs) baz kez"w zlerins ew apa jgea krakn ōrn mēkn e ways veroy greal sałmosn asa minč 'ew eōt'n ōr ew apay $k^{\prime}$ 'o č'araéamn [for č 'arakamn?] veran: zk'én A(stuco)v. "Write this so that X's ${ }^{79}$ son $\mathrm{X}$ will be lost. (Magic square) Make copies on seven pieces of paper of the talisman written above, take one, hold it over a fire and just before you cast it in say, 'Fill his face with dishonor.' Give the father's name of X son of X and then recite the Psalm, 'God, who is like unto you' up until the place where it says 'as a fire He burns the mountains, ${ }^{80}$

\footnotetext{
${ }^{78}$ Aslanian 2011, p. 89 and 92 fig. 4.

${ }^{79}$ Arm. filan, from the Turkish loan form of Arabic fülān, "somebody or other".

${ }^{80}$ Ps. 82.1, Astuac o $k^{\prime} e z$ nmanic ' $\bar{e}$ "O God, who may be likened to You?"; Ps. 82.14 ... orpēs boc" zi kizu zlerins "for as a fire He burns the mountains." The author may be citing from memory, since the precise first verse he cites is actually Ps. 88.8, Têr Astuac zawrut'eanc", o nmane $k^{\prime} e z$, "Lord God of hosts, who is like You?" Armenians in olden times knew much of the Psalter by heart; and numerous Psalms were employed for
} 
and then cast it into the fire. Recite as above once a day for seven days and then your *enemy... you, by God."

Fol. 45r. Gir siroy siracit mazn ays $\bar{e}$ surma šinē ač $k^{\prime} t$ sirēe $k^{\prime} e z$ anp $(a) t \check{c} a \dot{r}$. "A love spell: Take a hair of your beloved and use it to dab antimony around your eyes, and she will definitely love you."

Ayl gir siroy akriawi letin muškow heto pahē siren k'ez anpatčar. "Another love spell: keep a crow's liver together with musk (?), and they will definitely love you."

Wasn [sic!] hiwandi grē nerk'oy t'lismns aj jerin prinea tur t'ē cicałi apri t'ē lay merini. (Magic symbols) "For a sick man: write the talisman below on your right hand and have him seize it. If he laughs, he will live; if he cries, he'll die. (Magic symbols)"

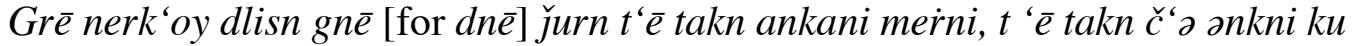
apri. Ays $\bar{e}$ : (Magic symbols) "Write the talisman below and put it in water. If it sinks to the bottom, he will die; if it doesn't sink to the bottom, he'll live. This is it: (Magic symbols)"

Fol. 46r. Xrat vasn anerewoyt 'ut 'ean ar dan maztak $V$ msxal ew gnay hangstarann. Krak tar hetd ew cxēe e(w) karda ays nerk'o greal anuank's minč'ew $V$

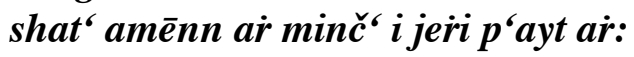

$\bar{o} \mathbf{s} \bar{e}$ mušin di mušin mēhr

dišn mēhrdišin mēhmēèēsēmi

ahiun ahiun ahran hēho

šin $\boldsymbol{k}^{6} u m s ̌ i n ~ m e \bar{e} m \bar{e} s ̌ u n ~ t^{\prime} \bar{e} r$

mušin aprašin $k^{6} e l s ̌ i n ~ h \bar{e} \bar{e} y$

elÿibēāe ors mazgel. Vēl

$\boldsymbol{k}^{\prime} \bar{e} l m a y \bar{e}$ mēr duk'xam

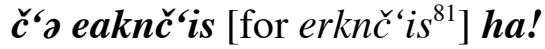

"Advice concerning invisibility: Take a portion of mastic, five measures, ${ }^{82}$ and go to your chamber. ${ }^{83}$ Take fire with you and suffumigate it and recite the names below, for five hours. ${ }^{84}$ Do it all while holding a staff in your hand. ${ }^{85}$ (Nomina barbara) ${ }^{86}$ Don't fear, then!"

magical purposes: see for example the modern magico-medical MS analyzed in Russell 2011.

${ }^{81} \mathrm{Cf}$. the instruction in the spell on Fol. 47r., infra, with the same word and injunction not to fear after performing a magical operation in a graveyard.

${ }^{82}$ Arm. msxal, for Arabic-in-Persian, mithqāl.

${ }^{83}$ Arm. hangstaran, lit. "place of rest" - a word for which our author gives a $\dot{R}$ štuni

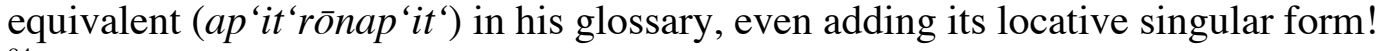

${ }^{84}$ Arm shat', for Arabic in Turkish sā'at.

${ }^{85}$ The word here is Arm. p'ayt, "piece of wood, stick", a term used also of the Tree of Life of the Cross; but the context here would indicate a magician's staff, analogous to the 
Gi[r] vasn siroy. Knoǰ kat'n kt'ea tur aynk'(a)n or XLIX msxal alurn xmorn è ayn uzacit nman pat [k? ]er šinēe ew apay ays t'lisms nerk'oy gre(a)l hasarak tan(a)k'ov grē $i$ $v(e) r(a y) t ' t t$ 'i ew kpc'ru i v(e)r(ay) xmorē pat [k? ]eri p'orin ew dir metm mōrmōti ǰro(y)

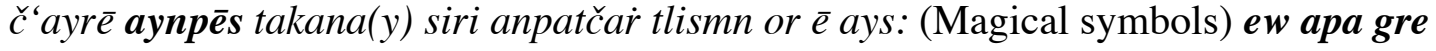
siracit ano(w)nn i groc's t'lmis t' $\bar{e}$ filani dustr filann inc sire ays $\bar{e}$. "Love spell: sprinkle enough of a woman's milk to make dough of forty-nine measures of flour. Make an image in the likeness of the one you desire. Then write in common ink this talisman written below and fasten it to the belly of the image made of dough, and place it in the juice of a soft bramble plant so that it doesn't burn, that way she may grow hot and definitely love you. This is the talisman: (Magical symbols) And then write the name of your beloved, in the writing of this talisman, thus: may X's daughter X love me."

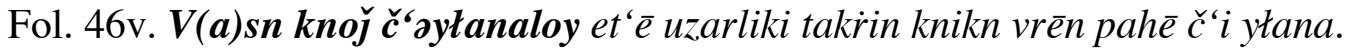
"For a woman's not becoming pregnant. If a woman keep over her the root of the wild rue $^{87}$ she will not become pregnant." Marginal note: bosxur mariam "starwort". ${ }^{88}$

Gir siroy. Smbuli catikn vardn ew manušakn et' $\bar{e} \check{c}^{`}$ orac'nes $\boldsymbol{i}$ miasin ew manr p'oši anes ew xarnes, dełin momi het um or k'ses sirē kez' anpatǰar. "Love spell: If you dry the hyacinth flower, rose, and violet and make a fine powder and mix them with yellow wax, whomever you rub with it will definitely love you."

gawazan "crozier, scepter" of a clergyman or noble, or the sword of an exorcist (see Russell 2000(a) and 2001).

${ }^{86}$ These rhyming nonsense words appear to contain Persian mehr, "love", and Turkish elčibey "emissary". As with the $\dot{R}$ štuni language, their phonetic un-Armenianness is stressed by the frequency of long vowels and the absence of sounds like /dz/ and /ch/. The intent here seems to be to mimic a spell in Persian. See Russell 2012(c) on nomina barbara and voces mysticae in Armenian magical texts.

${ }^{87}$ This is Peganum harmala, Tk. üzerlik otu, Pers. and Arm. s(i)pand (see Bedevian 1936, p. 444 no. 2575 and Gabikean 1968, p. 187, no. 1392: uzērlik, iwzēerlik in the Arm. dialect of Sebastia/Sivas) burned as incense by Iranians, who attribute to it numerous magical properties; the Iranian name means "holy", and Prof. Martin Schwartz has proposed that it was a component of the original mixture of entheogenic plants pounded in Indian and Zoroastrian sacrificial ritual, the Av. haoma, Ved. soma; and explains the Turkic name as meaning "conferring a hundred virile potencies" (Flattery and Schwartz 1989, pp. 149-150). As for the root the spell prescribes, the greatest amount of psychoactive components in Peganum harmala is in mature seeds (up to seven percent) and in the roots (up to just over three percent), but the latter is richest through the early part of the year till the former ripen (ibid., pp. 34, 82). The plant was believed by mediaeval Muslim doctors to induce menstrual flow (ibid., pp. 32-33); so perhaps this was a reason the Armenian magician-herbalist prescribes it against conception - after which a woman's menses stops until the child's birth.

${ }^{88}$ Ar. baxūr maryam, Tk. mariam buhuru, Arm. maremaxnkeni ("Mary's frankincense") or $p$ 'ok'r mškacatik "little musk flower"): Bedevian 1936, p. 435 no. 2521. 
Fol. 47r. Tatrak gir siroy tatragi jun xōrōwa ew č'orac'ru um or (e)w kirakri vrēn anes manr p'oši ara: $k^{\prime} e z$ sirē anpatčar. "Turtledove love spell: Roast the egg of a turtledove and dry it, then sprinkle it as a fine powder over the food of that person and (s)he will definitely love you."

Ays nerk'wo greal t'lismi grē tnkit vr(ay): zor ōrinak (Magical diagram). Ayspēs III ôr anc'eal lini III ôr(o)wan v(e)r(ay) gišern erku sahat'n anc'eal lini: gnay mereli gerezmani $v(e) r($ ay) yet koys parkil II jerōo $k$ ' $g$ [for $-d$ ] gerezmani hotic'n ver ar ayn hotn pind pahir ap'it mēèn šutov gas anc'anes mēk gnac'akan get ork'an ahac'uc'anen mi erknč 'ir oč' yet mtik tur oč jayn tur miaynak gnay. Ays hotis xasiat'n ays ē min p'ok'r ays hołic's eałluin kapē dnes mēk mardo(y) coc' inč' ban or xndres $\boldsymbol{k}^{\prime}$ ez kutay ew ink'n

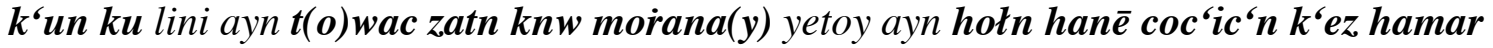

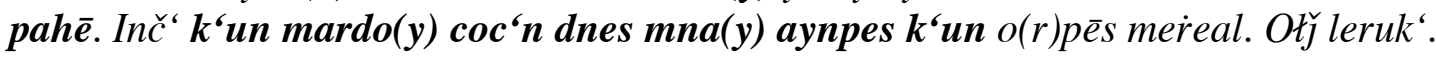
"Write the talisman below on your fingernail, as for instance thus: (Magical diagram) Let three days pass. Go to the grave of a dead man on the night of the third day after the second hour and lie upon it with a virgin. With both hands take up earth from that grave and grip it tightly in the palm of your hand, then come quickly to, and cross, a fordable river. No matter how much they terrify you, fear not. Pay no heed to what is behind you and don't let out a sound, just keep going. The function ${ }^{89}$ of this soil is that if you take just a little of it and bind it with butter ${ }^{90}$ and place it upon a man's breast, he will give you whatever you seek, while he himself will be asleep, and will forget whatever he had given (?). Then remove the soil from his breast and keep it for yourself. Any sleeping man's chest you put it on, he'll stay asleep like a corpse. Be ye well."

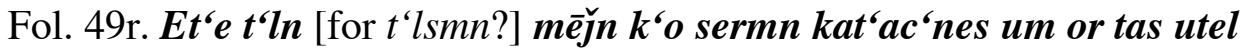
ař̌ăamayn $\boldsymbol{k}^{\prime} \boldsymbol{e} z$ sirē: ayspēs (Magical symbols). "If you ejaculate your semen onto this talisman, the person to whom you give it to eat will love you instantly. Thus: (Magical symbols)."

The text on Fol. 67r-v is not so much a spell, though it is of magical content, as a curiously garbled account of the Armenian magical flower called hamasp 'iwr (lit. "allspreading"), which first sprouted from the blood of martyrs, and to which are ascribed numerous virtues. ${ }^{91}$ The author of the MS has not got the name of the flower right and conceals it in cipher the two times it is mentioned; the rest is in Armenian plaintext. The

\footnotetext{
${ }^{89}$ Arm. xasiat', more commonly hasiat ' in magical texts, from Arabic-in-Persian: in the much-corrupted late Middle Armenian paraphrases of the Testament of Solomon, where the ancient king and archmage interrogates some seventy-two demons, "What is your hasiat "?" (i.e., role, function, specialty) is part of the standard list of questions posed to each spirit in turn. And the demon willingly recites both its particular baneful talent and the talisman capable of summoning and controlling it: see Russell 2012(c). The magical rite of MS A-29 apparently combines zombification with inducement of a comatose state. ${ }^{90}$ Arm. eałlu, i.e., standard Tk. ya ğ ll, "possessing or containing oil". One standard Western Armenian term for butter is ardar et or iwt, lit. "pure, righteous oil" (Riggs 1847, p. 8).

${ }^{91}$ See Russell 1997, pp. 93-94 with refs.
} 
misreading, hamarfiws, is of interest since as a standard Armenian compound the word hamasp ' $i w \dot{r}$ is not in the least esoteric or unusual, though the flower it denotes is probably mythical. One might not therefore exclude the possibility that he was miscopying a manuscript not his own in which the word was already written in cipher: in the cryptogram, the characters for $f$ and $p$ ' are nearly identical, and the characters for $s$ and $\dot{r}$, already adjacent in the order of the Mesropian alphabet and cipher alike, are 180degree inversions of each other. The cartonnage facing fol. 1r, as noted, is made of gluedtogether fragments of cipher text. Though its style of handwriting does not differ from that of the MS proper, the rather unlikely misreading of the word hamasp 'iwr and one's suggestion of the reason for it, as well as the presence of text in the cipher in the material of the cardboard binding, together allow the possibility that our author might not have been the inventor and sole user of the cryptogram. I have in a study of another cryptogram attested in many MSS coined the term "hetaerogram" for a cryptogram so widely shared by some guild or sodality (Gk. hetaira) as to be more a marker of belonging than a method of concealing information. Perhaps we deal, then, with a "hetaerogram" here, though that suggestion must remain hypothetical until and unless another MS by another hand comes to light. The author seems at the end of the brief text to have conflated the hamasp 'iwr with the mandrake (Arm. loštak), about whose human form and loud cry Armenians and others hold many superstitions in common.

Hamarfiws c(a)tki meknu(t')i(wn)ə: Dionēsēos imastasērn or akanates ełel ays hamarfiws całkis or ew banalik'd am(enayn) $k(a) p(a) c$ banerun. Anušahot burastanoc ‘ terewn kanač ' ew bolor or jax ač' $k$ ' $n$ uni i t(e)r ew ełern karmir ew šurǰ šini zinč ałełakn or inč' anē: catikn ciranagoyn $\bar{e}$, tełew aysp 'iwr. Kaputakd ink'n apa am(enayn) imastasirac" ew gitnakanac" ew yusumnasirac'. Ew yoržam ar̈nen zna hrom, jēt'n xaínen zna ew k'sen otin ew jerk'n eresn ew berann: XXII azgi lezun xōsi ew XXII gir grē ew $k(a) r d(a) y$. Ew yoržam širimē elanes am(enayn) całikk'xōsin ə(nd) $k^{\prime} e z$. Ew asen t'e zinč irac' detēn ew t'ē uzes or gtanes zna, i giwtn ôrc t'uxi leaŕn naranic' i garnoy $k$ 'ałak'n or arzrum $i$ bark'oy learn i jorn masanc' $i$ daštn masic' or hayer xaxway gnay: git i bolorn varagay learn, i gluxn III vēm kay, min vimac'n gtanes zšnorhali całiks ays: hastateay $i$ yunisi amsoy, XX̄̄ ew $i k^{\prime}$ 'ałoc' $i$ XIn ew III ōr i pah kac 'ir, ew ałač' $\bar{e}$ zhogin $s(u r) b$ or tay $k^{\prime} e z$. Ink'n piti elanē XXI ǰiwtē ew bažani X čiwt. Ew asen t'ē erb całikn otac' zēt mardoy glux šinay kam mnay ač 'k'it berann bac'zspē: $k$ 'ez $v(a) s(n) \overline{o c i n}$. A(stua)c yusac'ir ew gnay.

"Explanation of the hamasp ' $i w \dot{r}^{92}$ flower. Dionysus the philosopher was eyewitness to this flower, the hamasp ' $i w \dot{r}$, which is even the key to all things locked. It is sweet in scent in gardens; its leaf is green and it has an eye on the left on the leaf (?) that is red, and around it bends (?). Its flower is purple in hue, and in the place where it spreads out (?) it is blue. It is then for all philosophers and scholars and the studious. And when they take it to Rome, they compound it with oil and smear it on their feet, hands, faces, and mouths.

\footnotetext{
${ }^{92}$ The final $s$ instead of $\dot{r}$ seems to be a scribal error: in the cipher, the character for the latter is the former flipped vertically over.
} 
It speaks $22^{93}$ kinds of languages and writes and reads 22 alphabets. And when you emerge from the grave all the flowers talk with you. And they say that it is a medicine for various things. And if you want to find it, go to the village Ōrc ${ }^{94}$ of Black Mountain, from it, to the city of Karin which is Erzerum, to the mountain Bark'oy to the valley of Masunk' in the plain of Masis facing Xaxo. Find it around mount Varag: ${ }^{95}$ on the summit there stand three boulders, and on one of them you will find this flower full of grace. It is fully blossoming in the month of June, from the $20^{\text {th }}$, and on $11^{\text {th }} \mathrm{K}^{\text {' }}$ ałoc . And fast for three days and beseech the Holy Spirit that he may give it to you. It sprouts from 21 branches and divides into 10 branches. And they say that when the flower has feet like a man and rears its head or turns openmouthed to your eye, restrain it. ${ }^{96}$ It is (good) for you for snakes. Hope in God and go."

\section{LIST OF PLATES}

1. Institute of Oriental Manuscripts of the Russian Academy of Sciences, St. Petersburg, MS A 29, endpapers and fol. $1 \mathrm{r}$.

2. MS A 29, fols. 44 v.-45 r. with the table of the "Third Script".

3. MS A 29, fols. 45 v. -46 r.

4. MS A 29, fols. 46 v.-47 r.

5. MS A 29, fols. 66 v.-67 r. with the beginning of the history of the hamasp 'iwr flower.

6. MS A 29, fol. $67 \mathrm{v}$. with the conclusion of the history of the hamasp ' $i w \dot{r}$ flower.

7. The "Ałuan" or "dove" cipher (A.G. Abrahamyan, Hay gri ev grč 'ut'yan patmut'yun

["History of Armenian script and writing"], Erevan, pp. 220-221).

8. The Seh-lerai script (Stamatiadis 1921, p. 99).

9. The Seh-lerai script (Stamatiadis 1921, p. 100).

10. The Seh-lerai script (Stamatiadis 1921, p. 101).

11. Title page of Tghransar, Ans haïlanzar..., Smyrna, 1864.

12. Tingirtepe, Izmir, with statue of Rumi.

\section{BIBLIOGRAPHY}

Gevorg Abgaryan, “Č'arenc'i č'vercanvac cackagrerə” [“The undeciphered cryptograms of Charents”], Nork‘ 1991.8-9, Erevan, pp. 147-160.

\footnotetext{
${ }^{93}$ This is an unusual number for a magical text in that it has no obvious Pythagorean or other cosmological symbolism, though the Hebrew alphabet does have 22 letters. Perhaps the tradition is grabled here, as elsewhere, and the original had "XII" (Arm. $z b$; in cursive šełagir the first letter, for " $\mathrm{X}$ " can, if the contunation of the loop to the right of the vertical is hooked, easily be misread for $i$ "XX"). On 12 and 12000 in Armenian magicomystical writings see Russell 1989, p. 230.

${ }^{94}$ Could this be Urc (lit. "wild thyme"), where the Cross-stone of 1279 discussed above came from?

${ }^{95}$ This is the mountain south of Van with its famous monastery that contained a relic of the true Cross.

${ }^{96}$ These are the legendary characteristics, not of the hamasp 'iwri, but of the loštak ("mandrake").
} 
Levon Abrahamian and Nancy Sweezy, eds., Armenian Folk Arts, Culture, and Identity, Bloomington: Indiana University Press, 2001.

A.G. Abrahamyan, Haykakan cackagrut 'yun [“Armenian Cryptography”], Erevan: Erevan State University Press, 1978.

Douglas Adams, The Hitchhiker's Guide to the Galaxy, New York: Ballantine, 2005.

Michael Adams, Slang: The People's Poetry, Oxford: Oxford University Press, 2009.

Fr. Nersēs Akinean, Grigoris I Ałt'amarc'i, keank'ə ew k'ert'uacnerə [“Grigoris I of Ałt'amar: His Life and Poems”'], Vienna: Mxit'arean tparan, 1958.

Fr. Giwt Ałaneanc', Simēon Kat'ułikosi yišatakaranə, kensagrut'eamb ew yaweluacnerov ew canot' "ut'iwnnerov ["The Memorial of Simeon Catholicos, with Biography, Appendices, and Notes"], Diwan Hayoc" patmut'ean ["Record of Armenian History"], vol. III, Tiflis, 1894.

Paolo Albani and Berlinghiero Buonarroti, Aga Magéra Difúra: Dizionario delle lingue immaginarie, Bologna: Zanichelli, 1994.

Fr. Łewond Ališan, Ayrarat, Venice: S. Lazzaro, 1890.

Sebouh David Aslanian, From the Indian Ocean to the Mediterranean: The Global Trade Networks of Armenian Merchants from New Julfa, Berkeley: University of California Press, 2011.

Abraham Ayvazean, Šar hay kensagrut'eanc '["Series of Armenian Biographies"], Constantinople, 1893, part II.

Levon Azaryan, Haykakan xačk'arer ["Armenian khatchkars”], Holy See of Echmiadzin, 1978.

Alessandro Bausani, “About a curious mystical language Bāl-a i-Balan," East and West, Year IV, No. 3, Rome: IsMEO, 1954, pp. 234-238.

Alessandro Bausani, Geheim- und Universalsprachen: Entwicklung und Typologie, Stuttgart: Kohlhammer, 1970.

Armenag K. Bedevian, Illustrated Polyglottic Dictionary of Plant Names, Cairo: Argus \& Papazian Presses, 1936.

Zvi Ben-Dor Benite, The Ten Lost Tribes: A World History, Oxford: Oxford University Press, 2009. 
Marjorie Boulton, Zamenhof: Creator of Esperanto, London: Routledge and Kegan Paul, 1960.

George A. Bournoutian, Russia and the Armenians of Transcaucasia, 1797-1889, A

Documentary Record, Costa Mesa, CA: Mazda, 1998.

George A. Bournoutian, tr., Simēon Kat'oghikos Erewants'i, Jambr (Archival Chamber), Costa Mesa, CA: Mazda, 2009.

Mary Boyce, A History of Zoroastrianism, Vol. 1, Leiden: Brill, 1975.

Tyler Burge, “A Theory of Aggregates,” Nous 11.2, May 1977, pp. 109-111.

Glenn Burger, ed., Hetoum, A Lytell Chronicle: Richard Pynson's translation of "La Fleur des histoires de la terre d'Oriente”, Toronto: University of Toronto Press, 1988.

Yakov Chernikhov, Graficheskie shedevry Yakova Georgievicha Chernikhova [“The Graphic Masterpieces of Yakov Georgievich Chernikhov"], Berlin: Dom, 2009.

B.L. Č'ugaszyan and P.M. Muradyan, eds., Sayat' Nova, Xałer, Nmanahanut ‘iwn ["Sayat" Nova, Songs, Facsimile"], Erevan: Academy of Sciences of the Armenian SSR, 1963.

Philip K. Dick, Valis, Boston: Houghton Mifflin, 2011.

E. Drezen, Historio de Mondolingvo, $3^{\text {rd }}$ ed., Osaka: Pirato, 1967.

Umberto Eco, Serendipities: Language and Lunacy, Italian Academy Lectures, New York: Columbia University Press, 1998.

Mircea Eliade, Youth Without Youth and Other Novellas, tr. by Mac Linscott Ricketts, Columbus, OH: Ohio State University Press, 1988.

Daniel L. Everett, Don't Sleep, There Are Snakes: Life and Language in the Amazonian Jungle, New York: Vintage, 2008.

Ronald A. Farrell, “The Argot of the Homosexual Subculture," Anthropological Linguistics 14.3 (March 1972), pp. 97-109.

Charles Fossey, Notices sur les caractères étrangers, Paris: Imprimerie Nationale de France, 1948.

David Stophlet Flattery and Martin Schwartz, Haoma and Harmaline: The Botanical Identity of the Indo-Iranian Sacred Hallucinogen "Soma" and its Legacy in Religion, Language, and Middle Eastern Folklore, University of California Publications: Near 
Eastern Studies, Volume 21, Berkeley and Los Angeles: University of California Press, 1989.

Karapet Gabikean, Hay busašxarh [“The Armenian Botanical World”], Jerusalem: St. James', 1968.

Peter B. Golden, The King's Dictionary (The Rasūlid Hexaglot: Fourteenth Century Vocabularies in Arabic, Persian, Turkic, Greek, Armenian and Mongol), Leiden: Brill, 2000.

Andrew Colin Gow, The Red Jews: Antisemitism in an Apocalyptic Age, Leiden: Brill, 1995.

Loren Graham and Jean-Michel Kantor, Naming Infinity, A True Story of Religious Mysticism and Mathematical Creativity, Cambridge, MA: Harvard University Press, 2009.

Wayne G. Hammond and Christina Scull, J.R.R. Tolkien, Artist and Illustrator, Boston: Houghton Mifflin, 1995.

Wendy Heller, Lidia: The Life of Lidia Zamenhof, Daughter of Esperanto, Oxford: George Ronald, 1985.

$H L B B=$ Hayoc" lezvi barbarayin bararan ["Dialectological dictionary of the Armenian language"], Vols. 1-6, Erevan: Armenian Academy of Sciences, 2001-2010.

Gevorg Jahukyan, Hayeren stugabanakan bararan [“Armenian Etymological Dictionary"], Erevan: Asołik, 2010.

G. Khalat'iants, Armianskii epos v istorii Moiseia Khorenskago ["The Armenian epic in the history of Movsēs Xorenac'i'], Moscow, 1896.

Victor Klemperer, The Language of the Third Reich (LTI-Lingua Tertii Imperii, A Philologist's Notebook), New York: Continuum, 2000.

K. Kostaneanc', ed., Grigor Magistrosi t'tt'erə ["The Letters of Grigor Magistros"], Alexandropol, 1910.

Thomas Kühne, Belonging and Genocide: Hitler's Community, 1918-1945, New Haven, CT: Yale university Press, 2010.

Paul Lerman, “Argot, Symbolic Deviance, and Subcultural Delinquency,” American Sociological Review 32.2 (April 1967), pp. 209-224.

Yovhannēs Mandakuni, Čàrk' [“Orations”], Venice: S. Lazzaro, 1860. 
Hrach K. Martirosyan, Etymological Dictionary of the Armenian Inherited Lexicon, Leiden: Brill, 2010.

Yaron Matras, "The Romani element in German secret languages: Jewisch and Rotwelsch," in Y. Matras, ed., The Romani Element in Non-Standard Speech, Wiesbaden: Harrassowitz, 1998, pp. 193-230.

David W. Maurer, Language of the Underworld, Lexington, KY: University Press of Kentucky, 1981.

R.R. Mehrotra, Sociology of Secret Languages, Simla: Indian Institute of Advanced Study, 1977.

Gurgen Melikian, "On the Problem of Secret Languages and Slangs in Iran," Iran and the Caucasus 6.1-2, 2002, pp. 181-188.

A.A. Ōdabašyan, "Xosk'i hmayut'yunn u cesn Axtark'um" ["Verbal enchantment and ritual in magico-astrological texts"], Lraber hasarakakan gitut'yunneri, Erevan, 2000.1 (601).

Marc Okrand, The Klingon Dictionary, New York: Pocket Books, 1985, $2^{\text {nd }}$ ed., 1992.

Arika Okrent, In the Land of Invented Languages, New York: Spiegel and Grau, 2010.

Leonardo Olschki, The Myth of Felt, Berkeley: University of California Press, 1949.

Iosif Abgarovich Orbeli, Fol'klor i byt Moksa ["The Folklore and Everyday Life of Moks"], ed. Karen N. Yuzbashyan, Moscow: Nauka, 1982.

Iosif Abgarovich Orbeli, Izbrannye trudy v dvukh tomakh ["Selected works in two volumes"], Vol. II, ed. P.M. Muradyan, Erevan: Gitut'yun ["Science"], Armenian Academy of Sciences, 2002.

Ēlias Petropoulos, Kaliarnta: erasitekhnikē glōssologikē ereuna [English title, "Kaliarda, an Etymological Dictionary of Greek Homosexuals' Slang”], Athens: Nephelē, 1982.

Fr. Ep'rem Pōłosean, Guyumčean ew T'ankərean gerdastannerə [German title, Die Familien Kouyoumdjian und Tingir], Vienna: Mxit'arean tparan (MechitharistenBuchdruckerei), 1951.

Y.P. Pōłosean, Hačəni əndhanur patmut ‘iwnə ew šř̌akay Gōzan Tałi hay giwłerə ["The General History of Hajin and the Armenian Villages of the Surrounding Kozan Dagh"], Los Angeles, 1942.

Elias Riggs, A vocabulary of words used in modern Armenian but not found in the ancient Armenian lexicons, Smyrna: W. Griffitt, 1847. 
Ṙaffi (Yakob Melik'-Yakobean), Xač agołi hišatakaranə [“The Cross-Thief's Memorial”], Erker [“Works"], Vol. 2, Erevan: Haypethrat, 1962.

Stephen D. Rogers, A Dictionary of Made-Up Languages, Avon, MA: Adams Media, 2011.

J.R. Russell, “A Poem of St. Grigor Narekac'i,” Revue des Etudes Arméniennes 19, 1985, pp. 435-439.

J.R. Russell, Yovhannēs T'lkuranc' $i$ and the Mediaeval Armenian Lyric Tradition, University of Pennsylvania Armenian Texts and Studies 7, Atlanta, GA: Scholars Press, 1987.

J.R. Russell, “A Wandering Herder of Camels," Annual of Armenian Linguistics 8, 1987(a), pp. 5-15.

J.R. Russell, Zoroastrianism in Armenia, Harvard Iranian Series 5, Cambridge, MA, 1987(b).

J.R. Russell, "The Book of the Six Thousand: An Armenian Magical Text," Bazmavēp 147.1-4, Venice, 1989, pp. 221-243.

J.R. Russell, "On Mysticism and Esotericism among the Zoroastrians," Iranian Studies 26.1-2, 1993, pp. 73-94.

J.R. Russell, "On the Origins and Invention of the Armenian Alphabet," Le Muséon 107.3-4, 1994, pp. 317-333.

J.R. Russell, "On the name Mashtots," Annual of Armenian Linguistics 15, 1994 (b), pp. $67-78$.

J.R. Russell, "Liturgical Mysticism and the Narek," Revue des Etudes Arméniennes 26, 1996-7, pp. 427-439.

J.R. Russell, "Scythians and Avesta in an Armenian Vernacular Paternoster, and a Zok Paternoster" Le Muséon 110, fasc. 1-2, 1997, pp. 91-114.

J.R. Russell, tr. of Karapet Sital, The Heroes of Kasht: An Armenian Epic, Ann Arbor, MI: Caravan Books, Armenian and Caucasian Series, 2000.

J.R. Russell, “A Scholium on Coleridge and an Armenian Demon,” JSAS 10 (1998,1999 [2000(a)]), pp. 63-71.

J.R. Russell, “The Scepter of Tiridates,” Le Muséon 114.1-2, 2001, pp. 187-215.

J.R. Russell, "Room at the Inn: P'ut'kavank' and Sraoša," Festschrift Shaul Shaked, Jerusalem Studies in Arabic and Islam 26, 2002, pp. 205-215. 
J.R. Russell, "The Rime of the Book of the Dove (Stikh o Golubinoi knige): From Zoroastrian cosmology and Armenian heresiography to the Russian novel," in Christine Allison, Anke Joisten-Pruschke, and Antje Wendtland, eds., From Daena to Din: Religion, Kultur und Sprache in der iranischen Welt (Festschrift Prof. Dr. Philip Kreyenbroek), Wiesbaden: Harrassowitz, 2009, pp. 141-208.

J.R. Russell, "The Script of the Dove: An Armenian Hetaerogram," Journal of Armenian Studies, Belmont, MA, Vol. IX, Nos. 1-2, 2010, pp. 61-108.

J.R. Russell, “An Armenian magico-medical manuscript (Bzhshkaran) in the NAASR Collection," Journal of the Society for Armenian Studies 20, 2011, pp. 111-130.

J.R. Russell, "Hārūt and Mārūt: The Armenian Zoroastrian Demonic Twins in the Qur'ān Who Invented Fiction" (Irano-Judaica conference, Hebrew Univ., Jerusalem, Oct. 2010), in publication, J. Rubanovich and Shaul Shaked, eds, Irano-Judaica VII, Jerusalem (2012).

J.R. Russell, "Magic Mountains, Milky Seas, Dragon Slayers, and Other Zoroastrian Archetypes," Bulletin of the Asia Institute, Ann Arbor, MI, 2012(b).

J.R. Russell, "Languages of Men, Languages of Demons: Concerning Infernal Babble in Armenian Magical Manuscripts," (lecture at the University of Manchester, 9 November 2009) in publication, Festschrift Michael Stone, ed. Theo Van Lint, 2012(c).

J.R. Russell, "Mashtots and Nga'ara: Writing and Cultural Survival in Armenia and Rapa Nui", forthcoming in Theo Van Lint, ed., J.J.S. Weitenberg Memorial Volume, 2013.

J.R. Russell, “A Note on Armenian hrmštk-el," Festschrift Garnik Asatrian, forthcoming 2013(a).

J.R. Russell, "On An Armenian Magical Manuscript (Jewish Theological Seminary, New York, MS 10558)," in publication, Proceedings of the Israel Academy of Sciences and Humanities, Jerusalem, 2013(b).

David Salo, A Gateway to Sindarin, Salt Lake City: University of Utah Press, 2004.

Jesse Schotter, "Verbivocovisuals: James Joyce and the Problem of Babel," James Joyce Quarterly 48.1, Fall 2010, pp. 89-109.

Klaus Schubert, ed., Interlinguistics: Aspects of the Science of Planned Languages, Trends in Linguistics, Studies and Monographs 42, Berlin and New York: Mouton de Gruyter, 1989.

William Henry Sleeman, Ramaseeana: Or A Vocabulary Of The Peculiar Language Used By The Thugs, Calcutta: Military Orphan Press, 1836 (repr. Kessinger Publishing Legacy Reprints).

Daniel Sperber, "On the Unfortunate Adventures of Rav Kahana: A Passage of Saboraic Polemic from Sasanian Persia," in Shaul Shaked, ed., Irano-Judaica [I], Jerusalem: BenZvi Institute, 1982, pp. 82-100.

Garegin Sruanjteanc", Mananay [“Manna”], Constantinople, 1876. 
$\operatorname{Tg}(\mathrm{h})$ ransar [Petros T'ənkərean], "La lingvo Sehlerai" (tr. from Gk. by Anakreon Stamatiadis), Bizantio: Esperantikē Epitheōrēsis, Revue rédigée en esperanto, en Grec, et en Français, 1.3, Constantinople, 30 Sept. 1921, p. 64; $2^{\text {nd }}$ part in Bizantio 1.4, 31 Oct. 1921 , p. 99.

Tghransar, Ans Haïlanzar ou Alpha-Gnomonomic de Seh-lerai: ouvrage, Smyrne, 1864.

J.R.R. Tolkien, The Return of the King (Lord of the Rings, Part Three), Boston: Houghton Mifflin, 1955.

T'ovmay Arcruni, ed. K'. Patkanean, Patmut 'iwn tann Arcruneac ' ["History of the House of the Arcrunis"], St. Petersburg, 1887 (repr. as Thomas Artsruni, History of the House of Artsrunik', Delmar, NY: Caravan, 1991).

Robert W. Thomson, tr., Moses Khorenats 'i, History of the Armenians, Cambridge, MA: Harvard University Press, 1978.

Robert W. Thomson, tr., T'ovma Artsruni, History of the House of the Artsrunik', Detroit, MI: Wayne State University Press, 1985.

Daniēl Varužan, Banastełcakan erker ["Poetical Works"], Ant'ilias [Antelias, Lebanon]: Tparan Kilikioy Kat'ołikosut'ean [Press of the Catholicosate of the Great House of Cilicia], 1986.

Vardan Voskanian, "The Iranian Loan-Words in Lomavren, The Secret Language of the Armenian Gypsies," Iran and the Caucasus 6.1-2, 2002, pp. 169-180.

Xorenac'i: M. Abełean, S. Yarut'iwnean, eds., Movsisi Xorenac'woy Patmut' iwn Hayoc' [“The History of the Armenians of Movsēs Xorenac'i”], Tpłis [Tiflis], 1913.

Karen Nikitich Yuzbashian, Armianskie rukopisi v peterburgskikh sobraniiakh [“Armenian manuscripts in Petersburg collections"], Pravoslavnyi Palestinskii sbornik, vypusk 104, St. Petersburg: Rossiiskaia Akademiia Nauk, Imperatorskoe Pravoslavnoe Palestinskoe Obshchestvo, 2005. 